\title{
Advances in Electrochemical Impedance Spectroscopy Detection of Endocrine Disruptors
}

\author{
Lucian-Gabriel Zamfir ${ }^{1}$, Mihaela Puiu ${ }^{1}$ (D) and Camelia Bala ${ }^{1,2, *(D)}$ \\ 1 R\&D Center LaborQ, University of Bucharest, 4-12 Regina Elisabeta Blvd., 030018 Bucharest, Romania; \\ lucian-gabriel.zamfir@cdi.unibuc.ro (L.-G.Z.); elenamihaela.puiu@g.unibuc.ro (M.P.) \\ 2 Department of Analytical Chemistry, University of Bucharest, 4-12 Regina Elisabeta Blvd., \\ 030018 Bucharest, Romania \\ * Correspondence: camelia.bala@chimie.unibuc.ro; Tel.: +40-21-410-4888
}

Received: 1 October 2020; Accepted: 9 November 2020; Published: 11 November 2020

\begin{abstract}
Endocrine disruptors (EDs) are contaminants that may mimic or interfere with the body's hormones, hampering the normal functions of the endocrine system in humans and animals. These substances, either natural or man-made, are involved in development, breeding, and immunity, causing a wide range of diseases and disorders. The traditional detection methods such as enzyme linked immunosorbent assay (ELISA) and chromatography are still the golden techniques for EDs detection due to their high sensitivity, robustness, and accuracy. Nevertheless, they have the disadvantage of being expensive and time-consuming, requiring bulky equipment or skilled personnel. On the other hand, early stage detection of EDs on-the-field requires portable devices fulfilling the Affordable, Sensitive, Specific, User-friendly, Rapid and Robust, Equipment free, Deliverable to end users (ASSURED) norms. Electrochemical impedance spectroscopy (EIS)-based sensors can be easily implemented in fully automated, sample-to-answer devices by integrating electrodes in microfluidic chips. The latest achievements on EIS-based sensors are discussed and critically assessed.
\end{abstract}

Keywords: endocrine; biosensor; impedance; MIP; immunosensor; aptasensor

\section{Introduction}

Endocrine disruptors (EDs) are environmental contaminants that disrupt the normal functioning of the endocrine system in mollusk, crustacea, fish, reptiles, birds, and mammals. For humans, these compounds may cause cancerous tumors [1-3] and infertility [4]. Natural EDs originate in living organisms and can be either hormones (testosterone, estrogen, or progesterone) or mycotoxins such as zearalenone. Synthetic EDs can be found in plastic additives, industrial reagents, and waste. Some of the most common synthetic EDs are precursors in the production of rubber, pesticides and plastic additives such as atrazine, alkylphenols, bisphenol A (BPA) [5], parabens, perfluoroalkyl acids [6], phthalates and polychlorinated biphenyls (PCBs) [7]. A list of relevant EDs is given in Table 1.

A variety of analytical methods have been used for the detection of EDs, including liquid chromatography coupled with mass spectrometry (LC-MS) [8], gas chromatography coupled with mass spectrometry (GS-MS) [9], high-performance liquid chromatography (HPLC) coupled with fluorescence detection [10] or with mass spectrometry [11,12]. These methods usually require laborious and time-consuming steps for sample pre-concentration, and high amounts of reagents. By comparison, electrochemical sensors and biosensors offer advantages such as low cost, portability, and do not require complex pretreatment steps. Moreover, biosensors can be used for selective, fast, and direct detection of analytes in real samples. 
Table 1. List of relevant EDs compounds.

\begin{tabular}{|c|c|c|c|c|c|}
\hline Analyte & IUPAC Name & Chemical Structure & $\begin{array}{l}\text { Molecular Weight } \\
(\mathrm{g} / \mathrm{mol})\end{array}$ & Source & Ref \\
\hline $\begin{array}{l}\text { 17 } \beta \text {-estradiol } \\
\quad(\mathrm{E} 2)\end{array}$ & $\begin{array}{l}\text { (8R,9S,13S,14S,17S)-13-Methyl-6,7,8,9,11,12,14,15,16,17- } \\
\text { decahydrocyclopenta[a]phenanthrene-3,17-diol }\end{array}$ & & 272.388 & endogenous hormone, medication & {$[13]$} \\
\hline $\begin{array}{l}\text { Acetamiprid } \\
\text { (AAP) }\end{array}$ & $\begin{array}{l}\text { N-[(6-chloro-3-pyridyl)methyl]- } \\
\mathrm{N}^{\prime} \text {-cyano-N-methyl-acetamidine }\end{array}$ & & 222.678 & insecticide & [14] \\
\hline $\begin{array}{l}\text { Atrazine } \\
\text { (ATZ) }\end{array}$ & $\begin{array}{l}\text { 6-chloro-N2-ethyl-N4-(propan-2-yl)-1,3,5 } \\
\text {-triazine-2,4-diamine }\end{array}$ & & 215.69 & herbicide for grassy weeds in crops & {$[15]$} \\
\hline $\begin{array}{l}\text { Pentabromodiphenyl ether } \\
\text { (BDE-47) }\end{array}$ & 2,2',4,4'-Tetrabromodiphenyl ether & & 485.79 & flame retardant & {$[16]$} \\
\hline $\begin{array}{l}\text { Bisphenol A } \\
\text { (BPA) }\end{array}$ & 4,4'-(propane-2,2-diyl)diphenol & & 228.291 & $\begin{array}{l}\text { precursor to polycarbonates, plastic } \\
\text { and epoxy resins }\end{array}$ & [17] \\
\hline $\begin{array}{l}\text { Carbendazim } \\
\quad(\text { CBZ) }\end{array}$ & methyl 1H-benzimidazol-2-ylcarbamate & & 191.187 & fungicide & {$[18]$} \\
\hline Cortisol & $11 \beta, 17 \alpha, 21$-Trihydroxypregn-4-ene-3,20-dione & & 362.46 & endogenous hormone, medication & [19] \\
\hline $\begin{array}{l}\text { Dibutyl phthalate } \\
\text { (DBP) }\end{array}$ & Dibutyl benzene-1,2-dicarboxylate & & 278.348 & plasticizer & {$[20]$} \\
\hline $\begin{array}{l}\text { Dichloro-diphenyl-trichloroethane } \\
\text { (DDT) }\end{array}$ & 1-chloro-4-[2,2,2-trichloro-1-(4-chlorophenyl)ethyl]benzene & & 354.48 & pesticide & [21] \\
\hline $\begin{array}{l}\text { Di(2-ethylhexyl) phthalate } \\
\text { (DEHP) }\end{array}$ & Bis(2-ethylhexyl) benzene-1,2-dicarboxylate & & 390.564 & plasticizer & [22] \\
\hline
\end{tabular}


Table 1. Cont.

\begin{tabular}{|c|c|c|c|c|c|}
\hline Analyte & IUPAC Name & Chemical Structure & $\begin{array}{l}\text { Molecular Weight } \\
(\mathrm{g} / \mathrm{mol})\end{array}$ & Source & Ref. \\
\hline $\begin{array}{l}\text { Microcystin-LR } \\
\text { (MC-LR) }\end{array}$ & $\begin{array}{c}\text { (5R,8S,11R,12S,15S,18S,19S,22R)-15-[3- } \\
\text { (diaminomethylideneamino)propyl]- } \\
\text { 18-[(1E,3E,5S,6S)-6-Methoxy-3,5-dimethyl-7-phenylhepta- } \\
\text { 1,3-dienyl]-1,5,12,19-tetramethyl-2-methylidene-8- } \\
\text { (2-methylpropyl)-3,6,9,13,16,20,25-heptaoxo- } \\
\text { 1,4,7,10,14,17,21-heptazacyclopentacosane- } \\
\text { 11,22-dicarboxylic acid }\end{array}$ & & 995.189 & cyanobacteria toxin & [23] \\
\hline $\begin{array}{l}\text { Norfluoxetine } \\
\text { (NorFLX) }\end{array}$ & (S)-3-Phenyl-3-[4-(trifluoromethyl)phenoxy]propan-1-amine & & 295.305 & antidepressant & [24] \\
\hline $\begin{array}{l}\text { 3,3',4,4'-tetrachlorobiphenyl } \\
\text { (PCB-77) }\end{array}$ & 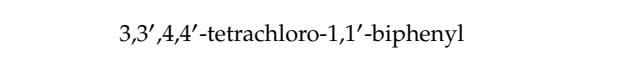 & & 291.99 & $\begin{array}{l}\text { flame retardants, plasticizers, dielectric } \\
\text { and heat transfer fluids }\end{array}$ & [25] \\
\hline Testosterone & $\begin{array}{l}\text { (8R,9S,10R,13S,14S,17S)-17-Hydroxy-10,13- } \\
\text { dimethyl-1,2,6,7,8,9,11,12,14,15,16,17- } \\
\text { dodecahydrocyclopenta[a]phenanthren-3-one }\end{array}$ & & 288.431 & endogenous hormone, anabolic steroid & [26] \\
\hline Tributyltin hydride & tributylstannane & & 291.06 & precursor in organic synthesis & [27] \\
\hline $\begin{array}{l}\text { Zearalenone } \\
\text { (ZEN) }\end{array}$ & $\begin{array}{l}\text { (3S,11E)-14,16-Dihydroxy-3-methyl-3,4,5,6,9,10- } \\
\text { hexahydro-1H-2-benzoxacyclotetradecine-1,7(8H)-dione }\end{array}$ & & 318.369 & mycotoxin & [28] \\
\hline
\end{tabular}


Electrochemical impedance spectroscopy (EIS) is a sensitive technique which can be used to monitor biomolecular events occurring at the electrode surface. These events include affinity interactions involving peptides, receptors, nucleic acids, whole cells, and antibodies.

This work reviews recent trends in the newly developed EIS sensors for the detection of EDs using different modified surfaces and various bioreceptors. In this review, significant examples of impedimetric sensors and biosensors for the detection of EDs are discussed and critically reviewed.

\section{Basic Elements of EIS-Based Sensors}

\subsection{Principle of EIS Detection}

Electrochemical impedance spectroscopy (EIS) is an electrochemical technique that measures the impedance properties of an electrochemical system using a large range of frequencies. Here, the electrochemical process is described by an electrical circuit consisting of resistance, capacitors, and constant phase elements combined in parallel or in series.

The most widely used model for describing processes at the electrochemical interface is the Randles equivalent circuit [29], consisting of electrolyte resistance $\left(R_{s}\right)$, charge-transfer resistance $\left(R_{c t}\right)$ at the electrode/electrolyte interface, double-layer capacitance $\left(C_{d 1}\right)$, mass transfer resistance $\left(R_{m t}\right)$ and Warburg impedance $(\mathrm{W})$. The $\mathrm{R}_{\mathrm{s}}$ parameter is determined by the conductivity of the solution and the distance between the electrodes. The double layer capacitance depends on the electrode area, nature, and electrolyte's ionic strength. $R_{c t}$ and $W$ represent the Faradaic impedance. $R_{c t}$ depends on the charge transfer kinetics and can be thought of as the ratio of overpotential to current in the absence of mass transfer limitation. The linear segment registered at low frequencies is attributed to the Warburg diffusion element, the impedance being controlled by the diffusion process in this region.

Equivalent circuit models can serve to describe the electrochemical, chemical, and physical processes occurring at the electrode surface, since each circuit component can be assigned to a physical process in the electrochemical cell. Electrochemical reactions involve electrolyte resistance, adsorption of electroactive species, charge transfer at the electrode surface, and mass transfer from the bulk solution to the working electrode surface. Each electrochemical process is represented by an electrical circuit that consists of capacitors, resistance and constant phase elements that are connected in parallel or in series.

EIS has been proven to be a useful tool for the analysis of interfacial or bulk electrical properties of the electrode, which can be used to quantitatively determine electrochemical processes [30]. EIS enables label-free detection with high signal-to noise ratio amenable to on-site analysis.

\subsection{Types of Impedance Sensors}

Impedance sensors can be classified according to the relation between the charge transfer process and the parameters measured into Faradaic or capacitive sensors (Figure 1).

(A) Faradaic impedance sensors use electrodes with conductive surfaces; the measurements require redox-active molecules in solution, such as hexacyanoferrate(II)/(III) anions or hexaammineruthenium (II)/(III) cations [31]. Charge transfer resistance $\left(\mathrm{R}_{\mathrm{ct}}\right)$ is the main parameter that characterizes the electrochemical process at the sensor's surface. The surface-binding of non-conductive molecules blocks the electron transfer (ET), causing an increase in $R_{c t}$. Conversely, the binding of conductive molecules or molecules able to catalyze redox reactions leads to the decrease in $R_{c t}$.

(B) Non-Faradaic (Capacitive) sensors are systems where the sensing surface is covered by an insulating layer. The double-layer capacitance $\left(C_{d 1}\right)$ is the main parameter that characterizes the reactions occurring at the electrolyte/electrode interface [32]. The binding of the molecules to the surface usually decreases the value of $C_{d 1}$. 
(a)
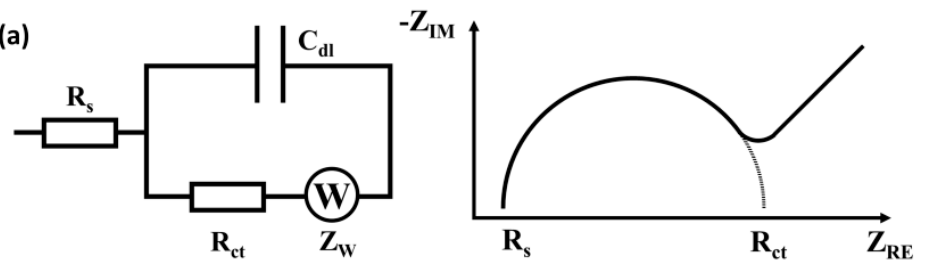

(b)

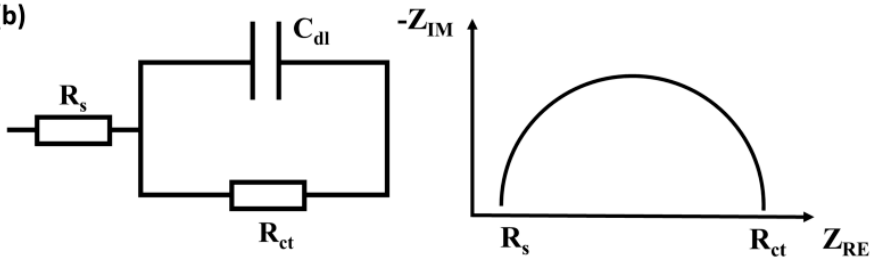

Figure 1. Common equivalent circuit models for EIS biosensors. (a) Faradaic systems with the Nyquist plot. (b) Non-Faradaic systems with the Nyquist plot. $R_{\mathrm{S}}=$ solution resistance; $R_{c t}=$ charge transfer resistance; $\mathrm{C}_{\mathrm{dl}}=$ double layer capacitance; $\mathrm{W}=$ Warburg element; $\mathrm{Z}_{\mathrm{RE}}=$ real impedance component; $\mathrm{Z}_{\mathrm{IM}}=$ imaginary impedance component.

\subsection{Electrochemical Impedance Spectroscopy for Biosensing Applications}

EIS also presents the possibility of carrying out label-free experiments, unlike other electrochemical techniques, such as amperometry and voltammetry [30]. The EIS sensors are often based on various modified surfaces that increase the amount of bioreceptor on the surface, and consequently the performance of the biosensor.

A biosensor is an analytical device in which a biological component, called a bioreceptor, is integrated or in direct contact with a physicochemical detector that turns the biological signal into a measurable analytical signal [33]. Biosensors offer a simple, rapid and cost-effective alternative for the detection of harmful compounds [34]. The bioreceptor is the component that interacts in a specific manner with the analyte, and can be an enzyme, antibody, nucleic acid, organelle, cell, or an organic tissue. The selectivity of the biosensor is determined by the affinity features of the biological receptor. The signal generated by the interaction between the analyte of interest and the biological recognition element is then transformed by a transducer to an optical or electrical readout. The EIS technique has been used to monitor specific interactions occurring at the electrode surface between a receptor and the specific target analyte; the impedance is used to quantitatively assess the analyte. The advantages of EIS biosensors are their sensitivity, simplicity, and possibility to achieve real-time detection. The use of EIS also has several disadvantages such as being sensitive to the surrounding environment, often requiring a Faraday cage to reduce noise, bulky experimental setups and the need for theoretical simulation for data analysis [35].

\section{EIS Sensors for EDs Detection}

Recently reported EIS sensors and biosensors for EDs detection have used various metal oxides [36], metal organic frameworks (MOFs) [37] and molecularly-imprinted polymers (MIPs) [38], either as supporting layers, or recognition elements. The immobilization strategy and the detection principles will be discussed further.

\subsection{Molecular-Imprinted Polymer Sensors}

MIPs are artificial recognition elements used in the development of sensors due to their high selectivity, chemical and thermal stability, and easy customization compared to receptors from biological sources. MIPs are created by polymerizing a functional monomer in the presence of the analyte template [39]. After the removal of the template, cavities with specific shapes are formed, allowing a highly selective interaction with the target analyte [40]. MIPs bind to the target molecules, leading to variations in physical parameters at the sensor surface, such as mass, absorbance, 
or electron transfer (ET) rate. In the case of electrochemical sensors, the specific interaction often hampers the electron transfer between the electrode and the redox probe in the solution, which can be quantified through EIS measurements. MIPs have been designed for the extraction of various EDs, such as 17 $\beta$-estradiol [38] or bisphenol A (BPA) [41] from contaminated environments. In MIP-based EIS sensors, the ED molecules fill the MIP cavities, hindering ET and thus increasing the $R_{c t}$ value. MIPs are usually immobilized on the sensor surface and interact with the analyte in solution.

A recent MIP-based sensor was developed for the impedimetric detection of 4,4'dichlorodiphenyltri-chloroethane $\left(4,4^{\prime}\right.$-DDT) by Miao et al. [42], based on magnetic $\mathrm{Fe}_{3} \mathrm{O}_{4}$ and polydopamine, using BPA as virtual template and dopamine as functional monomer. The obtained polydopamine (PDA)@ $\mathrm{Fe}_{3} \mathrm{O}_{4}$-MIP magnetic nanoparticles (MNPs) were incubated in the sample solution containing 4,4'-DDT; the composite material containing 4,4'-DDT molecules was separated from the solution with the help of a magnet and deposited further on a glassy carbon electrode (GCE) (Figure 2). The impedance of the resulting material was measured using EIS on a GCE. The method was used to determine $4,4^{\prime}$-DDT concentration over a range from $1 \times 10^{-11}$ to $1 \times 10^{-3} \mathrm{M}$ with a limit of detection (LOD) of $6 \times 10^{-12} \mathrm{M}$.

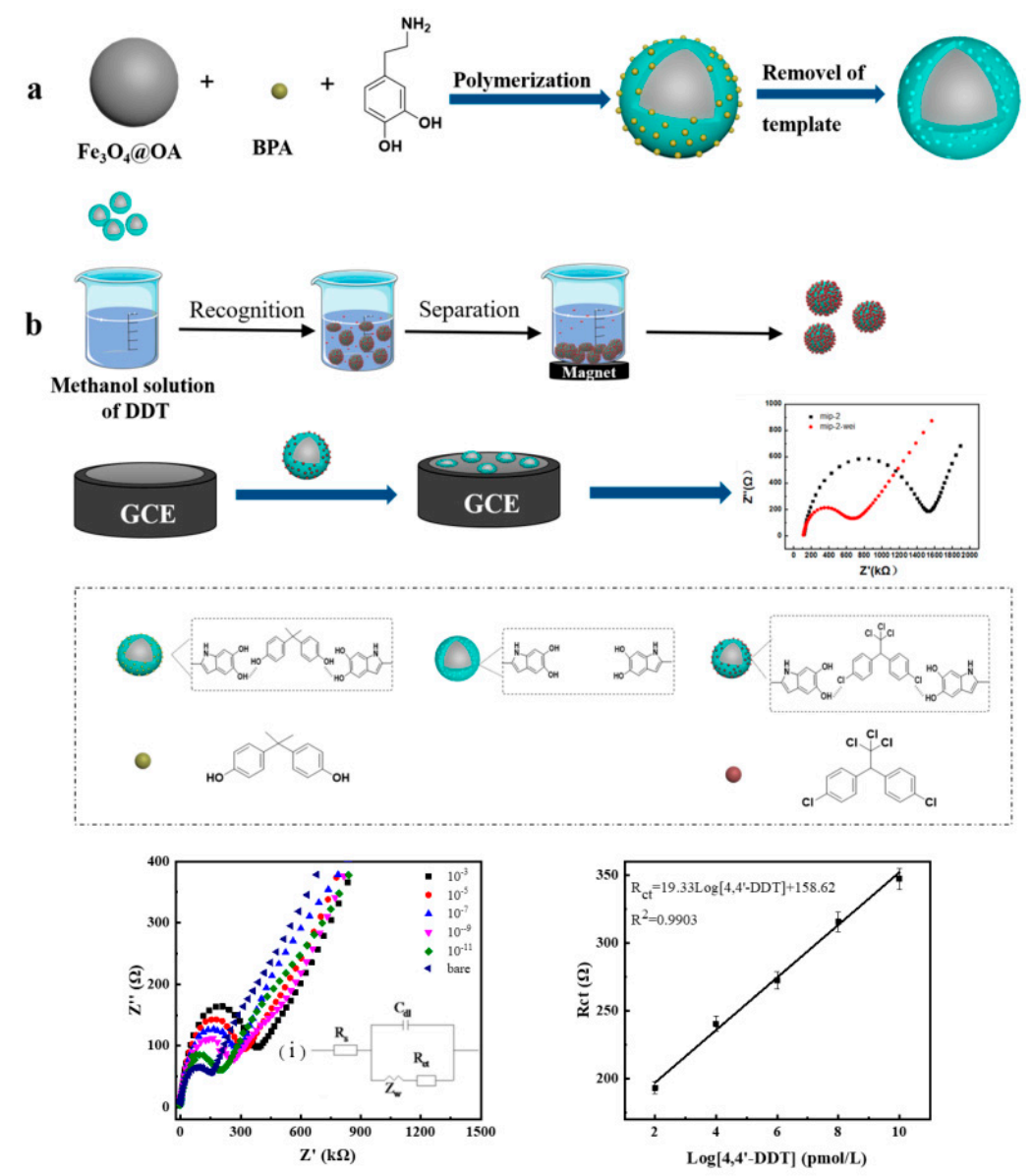

Figure 2. Schematic illustration of (a) synthesis of PDA@ $\mathrm{Fe}_{3} \mathrm{O}_{4}-\mathrm{MIP} \mathrm{MNPs}$ and (b) stepwise preparation process of the electrochemical impedance sensor for 4,4'-DDT detection. Reproduced from [42] with permission of Elsevier.

Radi et al. [43] developed a MIP sensor for the detection of zearalenone (ZEN) based on o-phenylenediamine (o-PD) electropolymerized on a screen-printed gold electrode and using the ZEN molecule as the template. The sensor showed low LOD and low cross-reactivity with other Fusarium mycotoxins. The latest achievements in the field are summarized in Table 2. 
Table 2. Impedimetric MIP-based sensors for EDs detection.

\begin{tabular}{|c|c|c|c|c|c|c|c|}
\hline Analyte & Platform & Linear Range & LOD & Real Sample & Advantages & Limitations & Ref. \\
\hline E2 & MIP/GCE & $1 \mathrm{aM}-1 \mu \mathrm{M}$ & $0.36 \mathrm{aM}$ & human serum & $\begin{array}{l}\text { Low detection limit; } \\
\text { High stability }\end{array}$ & $\begin{array}{l}\text { Multiple preparation and } \\
\text { optimization steps }\end{array}$ & [44] \\
\hline ATZ & MIP/GFE & 5-20 ppm & - & - & $\begin{array}{l}\text { High selectivity; } \\
\text { Simple modification protocol }\end{array}$ & Narrow linear range & [45] \\
\hline BPA & E-MIP/ITO & $1-12 \mathrm{mM}$ & $0.42 \mathrm{mM}$ & - & Selectivity & $\begin{array}{l}\text { Low sensitivity; } \\
\text { High detection limit; } \\
\text { Narrow linear range }\end{array}$ & [46] \\
\hline DBP & MIP-PPY/PGE & $0.01-1 \mu \mathrm{M}$ & $4.5 \mathrm{nM}$ & - & Simple modification protocol & Relatively high detection limit & [47] \\
\hline DDT & $\begin{array}{l}\text { PDA@ } \mathrm{Fe}_{3} \mathrm{O}_{4} \text {-MIP MNPs in solution, } \\
\text { EIS measurements on GCE }\end{array}$ & $1 \times 10^{-11}-1 \times 10^{-3} \mathrm{M}$ & $6 \times 10^{-12} \mathrm{M}$ & radish & $\begin{array}{l}\text { Reusability; } \\
\text { Wide linear range }\end{array}$ & $\begin{array}{l}\text { Long assay time; } \\
\text { Multiple preparation and } \\
\text { separation steps; } \\
\text { Requires a magnet }\end{array}$ & [42] \\
\hline DEHP & MIP-APTES SAM/AuIDE & 10-100 ppm & - & - & Low sample volume & $\begin{array}{l}\text { Narrow linear range; } \\
\text { Requires electrode fabrication }\end{array}$ & [48] \\
\hline DEHP & MIP/AuIDE, capacitive sensor & 10-200 ppm & - & - & Simple modification protocol & $\begin{array}{l}\text { Limited sensor reusability; } \\
\text { Narrow linear range }\end{array}$ & [49] \\
\hline Testosterone & poly(o-PD) MIP/GO/GCE & $1 \mathrm{fM}-1 \mu \mathrm{M}$ & $0.4 \mathrm{fM}$ & human serum & $\begin{array}{l}\text { Fast response time; } \\
\text { Low detection limit; } \\
\text { High stability }\end{array}$ & - & [50] \\
\hline Tributyltin & $\mathrm{MIP} \mathrm{Fe}_{3} \mathrm{O}_{4} \mathrm{NPs} / \mathrm{SPE}$ & $5 \mathrm{pM}-5 \mu \mathrm{M}$ & $5.37 \mathrm{pM}$ & sea water & $\begin{array}{l}\text { Large active surface area; } \\
\text { High sensitivity; } \\
\text { Wide linear range }\end{array}$ & $\begin{array}{l}\text { Multiple separation and } \\
\text { washing steps; } \\
\text { Requires a magnet }\end{array}$ & [51] \\
\hline ZEN & poly(o-PD) MIP/SPGE & $2.5-200 \mathrm{ng} / \mathrm{mL}$ & $2.5 \mathrm{ng} / \mathrm{mL}$ & corn flakes & $\begin{array}{l}\text { High selectivity; } \\
\text { Simple modification protocol; } \\
\text { Short incubation time }\end{array}$ & Narrow linear range & [43] \\
\hline
\end{tabular}

3-Aminopropyltriethoxysilane: APTES; Au interdigitated electrode: AuIDE; gold nanoparticles: AuNP; electropolymerized molecularly imprinted polymer: E-MIP; graphite felt electrode: GFE; graphene oxide: GO; indium tin oxide: ITO; pencil graphite electrode: PGE; polypyrrole: PPY; self-assembled monolayer: SAM; screen-printed electrode: SPE; screen-printed graphene electrode: SPGE. 
MIPs can also be prepared using biomolecules such as DNA fragments as templates. A MIP sensor developed by Ensafi et al. [52] using a DNA-based MIP achieved very low LODs for BPA. The modified sensor surface was obtained by electrodepositing AuNPs on a glassy carbon electrode and depositing a thiolated DNA sequence with high affinity for BPA ( $p-63)$ and free BPA. Pyrrole was electropolymerized on the surface of the GCE to entrap the BPA@p-63 complex, obtaining the MIP cavities that act as binding sites for BPA. The obtained PPY/@p-63/AuNP/GCE achieved one of the lowest LOD reported for an electrochemical sensor for BPA (80 aM). AuNPs enhance the active surface area of the electrode and, thus, the density of active sites, ultimately leading to improved sensitivity.

\subsection{Metal Composite-Based Sensors}

Metal composites represent a combination of two metals or a combination between a metal and another type of material, such as a polymer. Metal-polymer composites have a large surface area and enhanced electrical conductivity due to their mesoporous structures. Metal-organic frameworks (MOFs) are a class of compounds consisting of metal ions or clusters coordinated to organic ligands to form one-, two-, or three-dimensional structures. Due to their customizable structure and functionality, high porosity and large internal surface area, MOFs have great potential in electrochemical sensing applications [53]. However, there are few notable works reporting MOF-based sensors for EDs s detection with moderate performance, most of them not being tested on real samples.

A simple approach is based on the immobilization $\mathrm{MnO}_{2}$ on a gold electrode and this was integrated into a microfluidic platform [36]. The system was used for the detection of BPA within a linear range of $1 \mathrm{nM}-62.5 \mu \mathrm{M}$ with a detection limit of $0.66 \mu \mathrm{M}$. Cheng et al. [37] prepared a novel microfluidic system for the detection of the perfluorooctane sulfonate (PFOS), perfluoroalkyl pollutant and ED. The modified sensor uses a non-conductive mesoporous chromium terephthalate metal-organic framework (Cr-MIL-101, MIL Matérial Institut Lavoisier) as MOF receptor. The Cr-MIL-101 provided a higher surface area and higher affinity towards PFOS. The Cr-MIL-101 was immobilized on an interdigitated microelectrode array with sandwiched capture probes (Figure 3). The modified electrode was adapted into a microfluidic lab-on-a-chip sensing platform that achieved the detection of PFOS within a linear range of $0.5 \mathrm{ng} / \mathrm{L}-50 \mu \mathrm{g} / \mathrm{L}$ with a detection limit of $0.5 \mathrm{ng} / \mathrm{L}$, lower than other non-electrochemical detection methods.

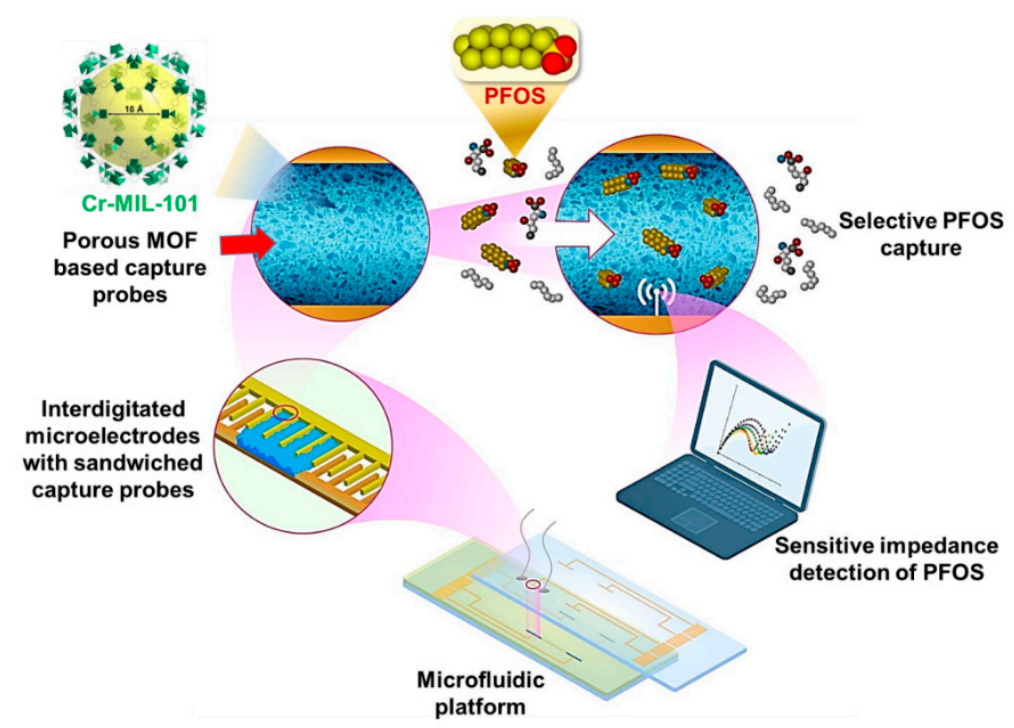

Figure 3. Schematic representation of PFOS detection using nanoporous MOF-based receptors immobilized on capacitive electrodes. The modified interdigitated microelectrodes were integrated within a microfluidic flow-through platform. Reproduced from [37]. Copyright (2020) American Chemical Society. 


\subsection{Graphene, Carbon-Nanotubes and Cyclodextrins Based Sensors}

Graphene is an allotrope of carbon with 2D layers of $\mathrm{sp}^{2}$-hybridized carbon. It is used for sensor modification due to its high electric conductivity and large surface area, which is amenable to functionalization with biomolecules. Single carbon nanotubes (SWCNT) and multiwalled carbon nanotubes (MWCNT) were used to modify the electrochemical transducers, due to their high electron transfer rate, surface area, minimization of the surface fouling and stability [54].

A simple approach for detecting polychlorinated biphenyls such as PCB-77 was developed by Wei et al. [55], where pyrenecyclodextrin (PyCD) was immobilized a SWCNT-modified GCE. The presence of the pyrenyl group on the $\mathrm{CD}$ favored the attachment on the surface of the carbon nanotubes trough $\pi-\pi$ stacking. The PCB-77 molecules formed complexes with the immobilized PyCD that hindered ET between the ferro/ferricyanide anions and the sensor surface. Thus, the $\mathrm{R}_{\mathrm{ct}}$ parameters increased with the concentration of PCB-77. The most relevant works on graphene, nanotubes and cyclodextrin modified EIS sensors are summarized in Table 3.

Table 3. Impedimetric sensors for EDs detection with graphene, carbon-nanotubes or cyclodextrins.

\begin{tabular}{|c|c|c|c|c|c|c|c|}
\hline Analyte & Platform & Linear Range & LOD & Real Samples & Advantages & Limitations & Ref. \\
\hline BPA & $\mathrm{Fe}(\mathrm{III}) \mathrm{TMPP} / \mathrm{TRGO} / \mathrm{Au}$ & $\begin{array}{c}1 \times 10^{-12} \\
-1 \times 10^{-8} \mathrm{M}\end{array}$ & $2.1 \times 10^{-13} \mathrm{M}$ & fresh milk & $\begin{array}{l}\text { High selectivity; } \\
\text { Wide linear range }\end{array}$ & $\begin{array}{l}\text { Additional preparation steps } \\
\text { for the electrode materials }\end{array}$ & {$[56]$} \\
\hline DEHP & $\begin{array}{c}\beta-\mathrm{CD}-\mathrm{GO} / \\
\mathrm{GCE}\end{array}$ & $2-18 \mu \mathrm{M}$ & $0.12 \mu \mathrm{M}$ & $\begin{array}{l}\text { wastewater from } \\
\text { plastics factory }\end{array}$ & High selectivity & $\begin{array}{c}\text { Narrow linear range; } \\
\text { Requires sample } \\
\text { deoxygenation }\end{array}$ & [57] \\
\hline DEHP & $\begin{array}{c}\mathrm{DEHP} / \beta-\mathrm{CD} / \mathrm{G} / \mathrm{DAD} / \\
\mathrm{GCE}\end{array}$ & $0.2-1.2 \mu \mathrm{M}$ & $0.01 \mu \mathrm{M}$ & river water & Good stability & $\begin{array}{c}\text { Multiple preparation and } \\
\text { optimization steps; } \\
\text { Narrow linear range }\end{array}$ & [58] \\
\hline PCB-77 & PyCD/SWCNT/GCE & $2-10 \mu \mathrm{M}$ & $1 \mathrm{nM}$ & - & High selectivity & $\begin{array}{l}\text { Long preconcentration time } \\
\text { (3h); } \\
\text { Narrow linear range }\end{array}$ & [55] \\
\hline
\end{tabular}

b-cyclodextrin: $\beta$-CD; 1,10-diaminodecane: DAD; graphene quantum dots: GQD; 3,3',4,4'-tetrachlorobiphenyl: PCB-77; pyrenecyclodextrin: PyCD; single-walled carbon nanotube: SWCNT; thermally reduced graphene oxide: TRGO; triflato 5,10,15,20-tetrakis (4-metoxyphenyl) porphyrinato iron (III): Fe(III)TMPP.

Recently, Hsine et al. [56] combined the use of a porphyrin derivative with that of thermally reduced graphene oxide (TRGO), which also can be attached using $\pi-\pi$ interactions. BPA molecules were absorbed on the surface of the nanocomposite, increasing the membrane resistance, which was quantified with EIS.

\section{EIS Biosensors for the Detection of EDs}

\subsection{Immunosensors}

Immunoassays are based on the specific interaction between an antigen and the corresponding antibody ( $\mathrm{Ab})$, which can be transduced into a measurable physical signal [59]. Immunosensors can be prepared using monoclonal, polyclonal or recombinant Abs. Immunosensors have been used for the detection of EDs, such as DES, estradiol, phthalates and bisphenol A [60]. The bonds between antibodies and antigens are relatively weak and can be dissociated by changing the properties of the environments, i.e., $\mathrm{pH}$ and ionic strength. Singh et al. developed a simple label-free immunosensor for 17 $\beta$-estradiol [61]. Silver wire electrodes were modified with an 11-mercaptoundecanoic acid self-assembled monolayer (SAM) and the 1-ethyl-3-(3-dimethylaminopropyl)carbodiimide (EDC)-N-hydroxy succinimide (NHS) chemistry was used to covalently bind the $17 \beta$-estradiol monoclonal antibodies. In this case, the parameter measured was the capacitance.

Another interesting approach was reported by Supraja et al. [62]. They have used MWCNT-ZnO hybrid nanofibers for electrode modification. MWCNT-ZnO nanofibers were deposed on GCE and treated with 3-sulfanylpropionoic acid to ensure the presence of - $\mathrm{COOH}$ groups. Anti-atrazine antibodies were immobilized via EDC-NHS coupling, and the remaining sites were blocked with BSA. The use of the MWCNT-ZnO nanofibers enhanced the surface area by $33 \%$ compared to the 
electrodes modified only with $\mathrm{ZnO}$, and thus increased the amount of anti-atrazine antibodies on the working electrode. Wang et al. [43] developed an immunosensor for the mycotoxin ZEN based on enzyme-catalyzed precipitation. Strip-shaped $\mathrm{Co}_{3} \mathrm{O}_{4}\left(\mathrm{ssCo}_{3} \mathrm{O}_{4}\right)$, a material with peroxidase-like activity, catalyzes the oxidation of 4-chloro-1-naphthol. The insoluble precipitate generated in this reaction was nonconductive and accumulated onto electrode, hampering the electron transfer between the redox probe to the working electrode. The glassy carbon electrode was first modified with hyaluronic acid (HA)-functionalized $\mathrm{TiO}_{2}$ mesocrystals $\left(\mathrm{TiO}_{2} \mathrm{MCs}\right)$. Then, an antibody, $\mathrm{Ab}_{1}$, was covalently attached to HA via EDC-NHS coupling. In this sandwich assay, the ZEN molecules bind to the $\mathrm{Ab}_{1} / \mathrm{HA}-\mathrm{TiO}_{2}$ MC/GCE immunosensor. $\mathrm{Ab}_{2} @ \mathrm{ssCo}_{3} \mathrm{O}_{4}$ conjugate binds the captured ZEN molecules, causing the accumulation of insoluble products at the surface and the increase in $\mathrm{R}_{\mathrm{ct}}$; thus, the concentration of ZEN was determined through EIS measurements. The most recent EIS immunosensors for ED detection are presented in Table 4.

Chen et al. used a tyramine-modified rutile $\mathrm{TiO}_{2}$ mesocrystals (Tyr-RMC) to label a ZEN mimic peptide [63]. The peptide@Tyr-RMC conjugate binds an antibody-modified GCE in competition with free ZEN. Although the peptide-based sensor was designed for an assay based on dual-signal readout competitive enzyme-linked immunosorbent assay (C-ELISA), the ZEN could also be detected by EIS, with the signal gradually decreasing while the concentration increases.

\subsection{Aptamer-Based Biosensors}

Aptamers are oligonucleotides that bind to a specific target. Because of their in vitro selection and production, the relatively new technology of aptamers has emerged as an alternative to antibodies, as they are obtained through chemical synthesis, with high reproducibility, and their production is not dependent on living organisms. They can be easily regenerated, have a much longer shelf life, and can be stored at ambient temperature. Several significant impedimetric aptasensors for the detection of EDs are presented in Table 5.

Kang et al. [64] developed a microfluidic aptasensor for the detection of BPA using an anodized aluminum oxide-based capacitive sensor. A gold electrode surface was immobilized on top of the Anodized aluminum oxide (AOO) surface and this allowed the immobilization of a thiol-modified BPA aptamer. The capacitance of the system decreased due to the conformational change of immobilized aptamer at the binding to the BPA molecules. The sensing surface was encased in a microfluidic channel and this allowed a real-time capacitance measurement during the binding of BPA to the immobilized aptamer. A capacitive aptamer microelectrode array has also been used for the detection of BPA, with aptamers immobilized on an array made of interdigitated aluminum microelectrodes [65]. The method combines AC electro-kinetics (ACEK) effects and capacitance measurement. The main advantages of the detection system are the low cost of the disposable microelectrodes, fast response time (20 s), and the limit of detection reported for BPA is $2.8 \mathrm{fg} / \mathrm{mL}$. Mirzajani et al. developed a BPA aptasensor in an ACET (alternating current electrothermal) flow based system [66]. The BPA aptasensor is based on printed circuit board technique combined with capacitive sensing (Figure 4). The ACET effect generates directional microflows and long-range convection of the BPA molecules to the electrode surface. To selectivity of the biosensors is also validated by using a flow containing a mixture of BPA molecules along with the interfering compounds bisphenol $\mathrm{S}$ and bisphenol $\mathrm{F}$. The capacitive biosensor achieved one of the lowest LODs for BPA reported in the literature (152.93 aM). 
Table 4. Impedimetric immunosensors for the detection of EDs.

\begin{tabular}{|c|c|c|c|c|c|c|c|}
\hline Analyte & Platform & Linear Range & LOD & Real Sample & Advantages & Limitations & Ref. \\
\hline E2 & $\mathrm{mAb} / 11-\mathrm{MUA} / \mathrm{Ag}$ wire electrode & $1-200 \mathrm{pg} / \mathrm{mL}$ & $1 \mathrm{pg} / \mathrm{mL}$ & water & $\begin{array}{l}\text { Fast response time; } \\
\text { Label-free; } \\
\text { Low sample volume; } \\
\text { High sensitivity }\end{array}$ & $\begin{array}{l}\text { Low stability compared to MIP and } \\
\text { aptamer-based systems; } \\
\text { Risk of cross-reactivity }\end{array}$ & [61] \\
\hline E2 & Ag-ZnONRs-16-PHA-mAb-E2 & $0.1-200 \mathrm{pg} / \mathrm{mL}$ & $0.1 \mathrm{pg} / \mathrm{mL}$ & tap and packaged water & $\begin{array}{l}\text { Label-free; } \\
\text { Low sample volume; } \\
\text { High sensitivity; } \\
\text { Fast response time }\end{array}$ & Multiple preparation and optimization steps & [67] \\
\hline ATZ & GCE/MNF/MPA/EDC-NHS/Ab & $1 \mathrm{zg} / \mathrm{mL}-1 \mu \mathrm{g} / \mathrm{mL}$ & $0.22 \mathrm{zg} / \mathrm{mL}$ & water & $\begin{array}{l}\text { Label-free; } \\
\text { High sensitivity; } \\
\text { Simple protocol; } \\
\text { Wide linear range }\end{array}$ & Requires blocking of non-specific sites & [68] \\
\hline ATZ & Ab-SPA-MWCNT-ZnO/GCE & $10 \mathrm{zM}-1 \mu \mathrm{M}$ & $5.368 \mathrm{zM}$ & - & $\begin{array}{l}\text { Label-free; } \\
\text { Low detection limit; } \\
\text { Wide linear range }\end{array}$ & $\begin{array}{l}\text { Multiple preparation steps; } \\
\text { Requires blocking of non-specific sites }\end{array}$ & [62] \\
\hline $\begin{array}{l}\text { BDE-47 } \\
\text { NorFLX }\end{array}$ & $\mathrm{Ab} / 11-\mathrm{MUA} / \mathrm{Au}$ electrode & $\begin{array}{l}0.01-0.40 \mu \mathrm{g} / \mathrm{mL} \\
0.02-0.32 \mu \mathrm{g} / \mathrm{mL}\end{array}$ & $\begin{array}{l}1.3 \mathrm{ng} / \mathrm{mL} \\
8.5 \mathrm{ng} / \mathrm{mL}\end{array}$ & - & Facile antibody regeneration & $\begin{array}{l}\text { Narrow linear ranges; } \\
\text { Risk of non-specific binding }\end{array}$ & $\begin{array}{l}{[69]} \\
{[69]}\end{array}$ \\
\hline BPA & Ab-nano-CP/GCE & $1-100 \mathrm{ng} / \mathrm{mL}$ & $0.3 \pm 0.07 \mathrm{ng} / \mathrm{mL}$ & human serum & Label-free & Narrow linear ranges & [70] \\
\hline Cortisol & $\mathrm{Ab} / \beta-\mathrm{MnO}_{2} \mathrm{CNs} / \mathrm{GCE}$ & $0.1 \mathrm{pM}-1500 \mathrm{pM}$ & $0.023 \mathrm{pM}$ & human sweat and saliva & $\begin{array}{l}\text { High stability; } \\
\text { Wide linear range }\end{array}$ & $\begin{array}{l}\text { Requires blocking of non-specific sites; } \\
\text { Requires sample deoxygenation }\end{array}$ & [71] \\
\hline DBP & $\begin{array}{l}\text { antigen/CS/MWCNTs@GONRs/GCE; } \\
\text { Ab2-AuNP conjugate }\end{array}$ & $5-500 \mathrm{ng} / \mathrm{L}$ & $7 \mathrm{ng} / \mathrm{mL}$ & pure, tap, pond and river water & $\begin{array}{l}\text { Low detection limit; } \\
\text { Low sample volume }\end{array}$ & Risk of non-specific binding & [72] \\
\hline MC-LR & $\mathrm{Ab} / \mathrm{MC}-\mathrm{LR} / 3 \mathrm{D}$ GF electrode & $0.05-20 \mu \mathrm{g} / \mathrm{L}$ & $0.05 \mu \mathrm{g} / \mathrm{L}$ & tap water & $\begin{array}{l}\text { High sensitivity; } \\
\text { Low detection limit }\end{array}$ & $\begin{array}{l}\text { Additional preparation steps for the } \\
\text { electrode materials; } \\
\text { Low stability of bound antibodies }\end{array}$ & [73] \\
\hline ZEN & $\begin{array}{c}\mathrm{Ab}_{2} @_{\mathrm{ssCo}} \mathrm{O}_{4} / \mathrm{ZEN} / \mathrm{Ab1} / \mathrm{HA}-\mathrm{TiO}_{2} \\
\mathrm{MC} / \mathrm{GCE}\end{array}$ & $\begin{array}{c}0.1 \mathrm{fg} / \mathrm{mL}-10 \\
\mathrm{pg} / \mathrm{mL}\end{array}$ & $33 \mathrm{ag} / \mathrm{mL}$ & beer & $\begin{array}{l}\text { Low detection limit; } \\
\text { Use of enzyme mimic }\end{array}$ & $\begin{array}{l}\text { Low resolution of sensing system; } \\
\text { Requires redox label }\end{array}$ & [74] \\
\hline ZEN & $\begin{array}{c}\text { peptide@Tyr-RMC, } \\
\mathrm{Ab} / \text { poly(Gly)/AuNCs/CNHs/GCE }\end{array}$ & $10^{-6}-10 \mathrm{ng} / \mathrm{mL}$ & $10^{-6} \mathrm{ng} / \mathrm{mL}$ & soybean sauce & $\begin{array}{l}\text { Fast response time; } \\
\text { Wide linear range }\end{array}$ & $\begin{array}{l}\text { Multiple preparation and optimization steps; } \\
\text { Requires blocking of non-specific sites; } \\
\text { Requires redox label }\end{array}$ & [63] \\
\hline
\end{tabular}

11-mercaptoundecanoic acid: 11-MUA; Au nanocones: AuNCs, 16-phosphonohexadecanoic acid 16-PHA; 2,2',4,4'-Tetrabromodiphenyl ether: BDE-47; carbon nanohorns: CNHs; dithiobis-N-succinimidyl propionate: DTSP; hyaluronic acid: HA; monoclonal antibody: mAb; monoethanolamine: MEA; electrospun manganese oxide nanofibers: MNF; manganese oxide cacti-like nanostructures: $\beta-\mathrm{MnO} 2 \mathrm{CNs}$; 3-mercaptopropionic acid: MPA; nano-particle comprised conducting polymer: nano-CP; polyglycine: poly(Gly); Zinc Oxide nanorods: ZnONRs. 
Table 5. Impedimetric aptamer (Apt) and DNA biosensors for the detection of EDs.

\begin{tabular}{|c|c|c|c|c|c|c|c|}
\hline Analyte & Platform & Linear Range & LOD & Real Samples & Advantages & Limitations & Ref. \\
\hline E2 & Apt/dendritic Au/BDD electrode & $1 \times 10^{-14}-1 \times 10^{-9} \mathrm{M}$ & $5 \times 10^{-15} \mathrm{M}$ & river water & $\begin{array}{l}\text { High sensitivity; } \\
\text { High specificity }\end{array}$ & - & [75] \\
\hline E2 & Apt/CDs/SPCE & $\begin{array}{c}1.0 \times 10^{-7}-1.0 \times 10^{-12} \\
\mathrm{M}\end{array}$ & $0.5 \times 10^{-12} \mathrm{M}$ & river water & $\begin{array}{l}\text { High selectivity; } \\
\text { High stability }\end{array}$ & $\begin{array}{l}\text { Additional preparation steps for the } \\
\text { electrode materials }\end{array}$ & [76] \\
\hline AAP & $\mathrm{MCH} / \mathrm{Apt} / \mathrm{AuNPs} / \mathrm{Au}$ electrode & 5-600 nM & $1 \mathrm{nM}$ & wastewater, tomatoes & Simple modification protocol & $\begin{array}{l}\text { Relatively low sensitivity; } \\
\text { Relatively narrow linear range }\end{array}$ & [77] \\
\hline AAP & MCH/Apt/Au/MWCNT-rGONR/GCE & $5 \times 10^{-14}-1 \times 10^{-5} \mathrm{M}$ & $1.7 \times 10^{-14} \mathrm{M}$ & - & Wide linear range & Long preparation procedure & [78] \\
\hline AAP & \multirow{2}{*}{ MCH/Apt/GOPTS/PtNPs/PMMA/IDE } & $10 \mathrm{pM}-100 \mathrm{nM}$ & $1 \mathrm{pM}$ & \multirow{2}{*}{ tap and bottled mineral water } & \multirow{2}{*}{ High sensitivity } & \multirow{2}{*}{$\begin{array}{l}\text { Long incubation time }(60 \mathrm{~min}) \text { due to } \\
\text { large custom-made electrochemical cell }\end{array}$} & [79] \\
\hline ATZ & & $100 \mathrm{pM}-1 \mu \mathrm{M}$ & $10 \mathrm{pM}$ & & & & [79] \\
\hline BPA & Apt-Au/AOO, capacitive biosensor & $1 \times 10^{-9}-1 \times 10^{-7} \mathrm{M}$ & $100 \mathrm{pM}$ & - & $\begin{array}{l}\text { High sensitivity; } \\
\text { Microfluidic system }\end{array}$ & $\begin{array}{l}\text { Requires custom-made electrodes; } \\
\text { Single-use device }\end{array}$ & [64] \\
\hline BPA & $\mathrm{Apt} / \mathrm{Cu}^{2+} / \mathrm{PPY}-\mathrm{NTA} / \mathrm{GCE}$ & $10^{-11}-10^{-6} \mathrm{M}$ & $1.24 \times 10^{-12} \mathrm{M}$ & - & $\begin{array}{l}\text { Simple modification protocol; } \\
\text { Wide linear range }\end{array}$ & - & [80] \\
\hline BPA & $\mathrm{MCH} / \mathrm{Apt} / \mathrm{Au}-\mathrm{NPs} / \mathrm{BDD}$ & $1 \times 10^{-14}-1 \times 10^{-9} \mathrm{M}$ & $7.2 \times 10^{-15} \mathrm{M}$ & spiked milk & $\begin{array}{l}\text { Low detection limit; } \\
\text { Simple modification protocol }\end{array}$ & & [81] \\
\hline BPA & $\begin{array}{l}\text { Apt/interdigitated aluminum } \\
\text { microelectrode, capacitive biosensor }\end{array}$ & $1 \mathrm{fM}-1 \mathrm{pM}$ & $10 \mathrm{fM}$ & human serum & $\begin{array}{l}\text { Fast response time (20s); } \\
\text { High sensitivity; } \\
\text { Low sample volume }\end{array}$ & - & [65] \\
\hline BPA & PPY/BPA@p-63/AuNP/GCE & $0.5 \mathrm{fM}-5 \mathrm{pM}$ & $80 \mathrm{aM}$ & $\begin{array}{l}\text { fresh milk, milkpowder, tap and } \\
\text { pretreated water in baby glass }\end{array}$ & $\begin{array}{l}\text { Low detection limit; } \\
\text { Short assay time }\end{array}$ & - & [52] \\
\hline BPA & Apt/IDE, capacitive biosensor & $1 \mathrm{fM}-10 \mathrm{pM}$ & $152.93 \mathrm{aM}$ & - & $\begin{array}{l}\text { Fast response time (20s); } \\
\text { Low detection limit }\end{array}$ & - & [66] \\
\hline BPA & MB-DNA/MWCNTs-CS/PdNPs/C60/GCE & $0.5-25 \mu \mathrm{M}$ & $0.35 \mu \mathrm{M}$ & - & $\begin{array}{l}\text { Detection of DNA damage } \\
\text { induced by ED }\end{array}$ & $\begin{array}{l}\text { Relatively low sensitivity; } \\
\text { Narrow linear range }\end{array}$ & [82] \\
\hline CBZ & $\mathrm{MCH} / \mathrm{Apt} / \mathrm{Au}$ electrode & $10 \mathrm{pg} / \mathrm{mL}-10 \mathrm{ng} / \mathrm{mL}$ & $8.2 \mathrm{pg} / \mathrm{mL}$ & mango juice, soya milk, tomato, plum & Simple modification protocol & Long preparation time & [83] \\
\hline CBZ & $\mathrm{MCH} / \mathrm{Apt} / \mathrm{AuNPs} / 1-\mathrm{AP}-\mathrm{CNHs} / \mathrm{GCE}$ & $1-1000 \mathrm{pg} / \mathrm{mL}$ & $0.5 \mathrm{pg} / \mathrm{mL}$ & lettuce andorange juice & High selectivity & Long preparation time & [84] \\
\hline DEHP & Apt/AuNPs/MCH/Au & $7.629 \mathrm{pg} / \mathrm{mL}-2 \mu \mathrm{g} / \mathrm{mL}$ & $0.103 \mathrm{pg} / \mathrm{mL}$ & tap water & $\begin{array}{l}\text { High sensitivity; } \\
\text { Low detection limit }\end{array}$ & - & [85] \\
\hline
\end{tabular}

1-aminopyrene modified carbon nanohorns: 1-AP-CNHs; anodized aluminum oxide: AOO; boron-doped diamond: BDD; fullerene C60: C60; carbon dots: CDs; chitosan: CS; (3-glycidyloxypropyl) triethoxysilan: GOPTS; interdigitated electrode: IDE; methylene blue: MB; 6-mercapto-1-hexanol: $\mathrm{MCH}$; multiwalled carbon nanotubes: MWCNTs; palladium nanoparticles: Pd NPs; poly(methylmetacrylate: PMMA; pyrrole-nitrilotriacetic acid monomer: PPY-NTA; platinumnanoparticles: PtNPs; reduced graphene oxide nanoribbon: rGONR 


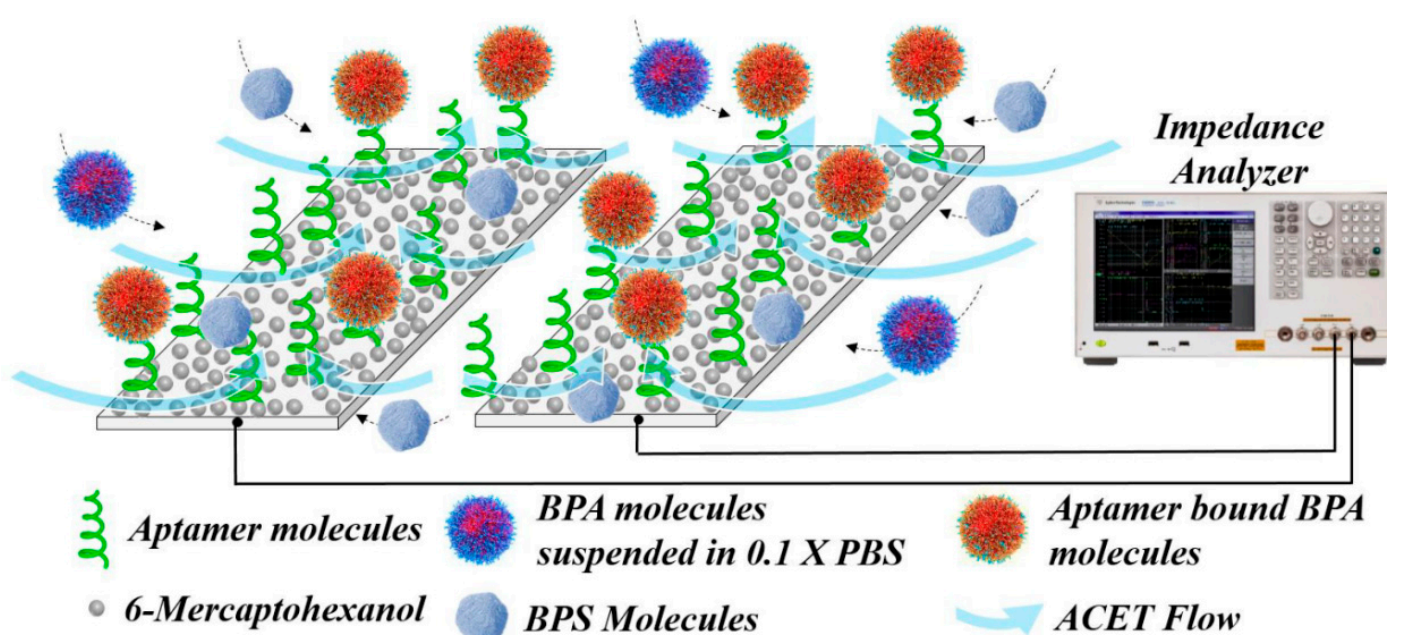

Figure 4. Excitation of ACET effect is integrated into capacitance measurement during a BPA detection experiment. The ACET flow carries BPA particles, along with Bisphenol S and Bisphenol F as interfering compounds, toward functionalized sites and accelerate the sensor response. Reproduced from [66] with permission of Elsevier.

\subsection{Estrogen Receptor-Based Biosensors}

Human-estrogen receptor alpha $(E R-\alpha)$ is a protein that belongs to the nuclear receptor group and can bind xenoestrogens such as $17 \beta$-estradiol. Due to its specificity and ability to be engineered, ER- $\alpha$ was used as bio-recognition element for the development of ED detection methods [86]. Estrogen receptor-based biosensors are not often encountered, but it is worth mentioning some notable works (Table 6).

Table 6. Estrogen receptor-based impedimetric biosensors for the detection of EDs.

\begin{tabular}{|c|c|c|c|c|c|c|c|}
\hline Analyte & Platform & Linear Range & LOD & Real Samples & Advantages & Limitations & Ref. \\
\hline E2 & ER- $\alpha / \mathrm{AuNPs} / \mathrm{s}-\mathrm{BLM} / \mathrm{Pt}$ & $5-150 \mathrm{ng} / \mathrm{L}$ & $1 \mathrm{ng} / \mathrm{L}$ & river water & $\begin{array}{l}\text { Does not require blocking of } \\
\text { non-specific sites; } \\
\text { Label-free; } \\
\text { Simple modification protocol }\end{array}$ & $\begin{array}{l}\text { Low stability; } \\
\text { Narrow linear range; } \\
\text { Only detects total } \\
\text { estrogenic activity }\end{array}$ & [87] \\
\hline E2 & ER- $\alpha / 3-\mathrm{MPA} / \mathrm{Au}$ & - & - & - & $\begin{array}{l}\text { Label-free; } \\
\text { Simple modification protocol }\end{array}$ & $\begin{array}{l}\text { Only detects total } \\
\text { estrogenic activity; } \\
\text { Requires blocking of } \\
\text { non-specific sites }\end{array}$ & [88] \\
\hline E2 & ER- $\alpha / 3-\mathrm{MPA} / \mathrm{Au}$ & $\begin{array}{c}1 \times 10^{-13}-1 \times 10^{-9} \\
M\end{array}$ & $1 \times 10^{-13} \mathrm{M}$ & human urine & $\begin{array}{l}\text { Label-free; } \\
\text { Simple modification protocol; } \\
\text { Wide linear range }\end{array}$ & $\begin{array}{l}\text { Longer incubation time } \\
\text { ( } 90 \text { min); } \\
\text { Only detects total } \\
\text { estrogenic activity; } \\
\text { Requires blocking of } \\
\text { non-specific sites }\end{array}$ & [89] \\
\hline E2 & ER- $\alpha / 3-\mathrm{MPA} / \mathrm{Au}$ & $3.7 \times 10^{-4}-3.7 \mathrm{ng} / \mathrm{L}$ & $3.7 \times 10^{-4} \mathrm{ng} / \mathrm{L}$ & - & $\begin{array}{l}\text { Label-free; } \\
\text { Simple modification protocol }\end{array}$ & $\begin{array}{l}\text { Only detects total } \\
\text { estrogenic activity; } \\
\text { Requires blocking of } \\
\text { non-specific sites }\end{array}$ & [90] \\
\hline
\end{tabular}

3-mercaptopropionic acid: 3-MPA; bilayer lipid membranes: s-BLM.

Im et al. [88] developed an EIS biosensor for $17 \beta$-estradiol based on the biding of estrogen to the surface-immobilized estrogen. The surface modification of the Au electrode involved the use of 3-mercaptopropionic acid (3-MPA), which binds to the Au surface via thiol groups and the ECD-NHS chemistry for the covalent binding of the estrogen receptor-alpha (ER- $\alpha$ ) to the carboxyl groups of 3-MPA. The hormone has been detected at a concentration of $10^{-6} \mathrm{M}$. The biosensor was developed further by the same group [89] by using BSA to block the remaining binding sites. The dynamic range was within $1 \times 10^{-13}-1 \times 10^{-9} \mathrm{M}$ with a LOD of $1 \times 10^{-13} \mathrm{M}$. 


\subsection{Enzyme-Based Biosensors}

Other biorecognition elements, such as enzymes, were used to develop the ED biosensors. In the case of phenolic compounds, these biosensors are often based on the enzymatic oxidation by enzymes such as tyrosinase [91] or laccase [92]. Metal composites have been used to modify the working electrodes and to provide a large surface area for enzyme immobilization and improved surface charge transfer.

Singh et al. [93] developed a tyrosinase biosensor for the impedimetric detection of BPA. The sensing surface used was based on nanostructured $\mathrm{TiO}_{2}$ that was functionalized further with an 3-Aminopropyltriethoxysilane (APTES)-based SAM and glutaraldehyde. The enzyme tyrosinase was covalently immobilized on the modified surface. The immobilized tyrosinase oxidized BPA to 2,2-bis(phenylquinone)propane and the resulting electrons were transferred to the $\mathrm{nTiO}_{2} / \mathrm{Ti}$ electrode, which led to a decrease in the $R_{c t}$ value (Figure 5). A linear relationship between variation of the $R_{c t}$ and concentration of BPA was observed within a linear range of $0.01-1.0 \mu \mathrm{M}$. The Tyrs-APTES/nTiO $/ 2 / \mathrm{Ti}$ biosensor achieved a LOD of $0.01 \mu \mathrm{M}$.

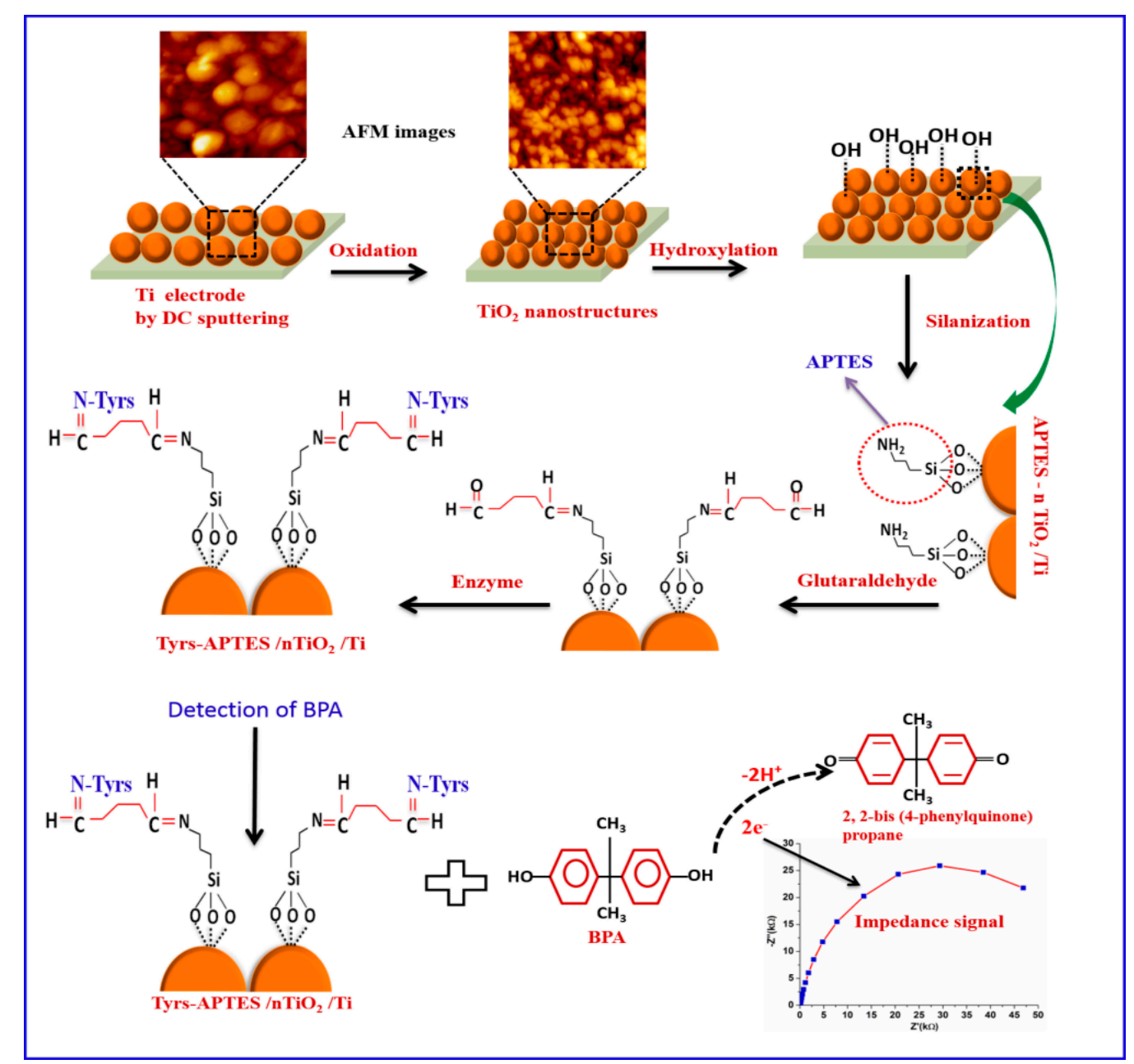

Figure 5. Preparation of the Tyrs- APTES $/ \mathrm{nTiO}_{2} / \mathrm{Ti}$ biosensor: the Ti electrode was modified using self-assembled direct current (DC) sputtered nanostructured rutile $\mathrm{TiO}_{2}$ aiming the covalent immobilization of tyrosinase. The oxidation of BPA caused changes in the charge transfer properties of the interface, monitored through EIS measurements. Reproduced from [93] with permission of Elsevier.

Recently, a laccase biosensor for BPA detection was developed using a conjugate containing reduced graphene oxide and ferrous-ferric oxide nanoparticles ( $\mathrm{rGO}-\mathrm{Fe}_{3} \mathrm{O}_{4} \mathrm{NPs}$ ) [94]. Chit95 (chitosan with a degree of deacetylation of $95 \%$ ) was used for laccase immobilization. The modified biosensor 
was used for both amperometric and impedimetric detection. Laccase (source: Trametes versicolor) catalyzes the oxidation reaction of p-diphenols. The biosensor provided a linear range of $0.025-20 \mu \mathrm{M}$ and a LOD of $65 \mathrm{nM}$ using EIS detection.

\subsection{Peptide-Based Biosensors}

Peptides are oligomers and polymers that can be customized with highly controlled preparation methods, due to the variety of natural and synthetic amino acids available for synthesis. Peptides have been employed in biosensing due to their specificity, better chemical and conformational stability compared to antibodies [95], low cost and facile synthesis and modification protocols that allow customization for a wide variety of applications [96].

Gutés et al. [97] reported a novel peptide-based biosensor for the detection of decabromodiphenyl ether (DBDE). The supporting electrode was prepared by growing graphene on a copper foil, decorating with AuNPs and spin-coating with poly(methylmetacrylate) (PMMA). The composite materials were transferred on a GCE. The DBDE binding peptide sequence, WHWNAWNWSSQQ, was immobilized by incubation of the AuNP-functionalized graphene electrode. The peptide-AuNP-graphene modified electrode was used for the EIS determination of polybrominated diphenyl ethers (PBDEs) and provided a response to molecules with similar structure and the biosensor showed little interference from similar compounds such as diphenyl ether.

\subsection{Microbial Biosensors}

Microbial biosensors use microorganisms as a sensitive biological element. Their main advantage is the fact that, unlike molecule-based biosensors, they provide information on toxicity or bioavailability [98]. The microbes are usually genetically engineered by modifying their structure to serve as bio-receptors for the target molecule [99].

Furst et al. have developed an electrochemical sandwich assay that measures the total estrogenic activity of a sample [100]. E. coli cells were engineered to display the estrogen receptor $\alpha($ ER- $\alpha)$ capture agent, while a synthesized antibody mimic protein was immobilized on a gold electrode via cysteine gold chemistry. The ED molecules first bind the receptor proteins anchored onto the surface, then E. coli cells from solution attach to the receptor-bound ED, thus causing the increase in EIS signal. The system was used for the detection of estrogenic activity in solutions containing $17 \beta$-estradiol, 4-nonylphenol, genistein and DES. The calculated LOD for $17 \beta$-estradiol was 500 pM. The method did not detect individual compounds but allowed the estimation of the total estrogenic activity.

\section{Conclusions}

EIS (bio)sensors have been increasingly used over the past decade since they are versatile, easy to functionalize and amenable for on-site field detection. Novel materials and capture elements have been developed to enhance the performance of ED detection even in complex matrices. Still, in label-free assays, EIS has to be used with precaution for avoiding false positive results, related to the interface dynamics and its inherently low signal-to-noise ratio [101]. In the absence of a laborious experimental control associated with an understanding of EIS concepts, variations caused by drift or non-specific binding can be mistakenly interpreted as specific interaction, thus compromising the analysis outcome. Although Faradaic EIS platforms are overwhelmingly used for label free detection, more and more papers have reported EIS sensors with surface-confined redox probes, where the non-Faradaic methodology (i.e., measuring changes in the dielectric properties at the target binding) was better suited for cost-effective, ultra sensitive and at point-of-use devices [102]. Due to their tunable nature and simple design, MIPs, aptamer, and peptide-modified biosensors represent reliable, inexpensive alternatives to the detection methods that use classical capture elements. Biosensors with biomolecules immobilized on different functional nanomaterials, (carbon nanotubes, graphene, graphite and related) display an increased number of the binding sites, enhanced stability, and facile electron transfer. Aptasensors are among the most sensitive biosensors, allowing the detection of the femtomolar 
concentration of several EDs, such as BPA. The implementation of Faradaic and non-Faradaic sensors in microfluidic systems allows rapid detection with minimal consumption of samples and reagents. Additional efforts are required to develop performing "lab-on-a-chip" sensing devices by coupling EIS detection with mass-sensitive techniques such as surface acoustic wave (SAW) and surface plasmon resonance (SPR). These tandem-interrogation concepts may provide promising tools for the development of robust, user-friendly sample-to-answer platforms.

Author Contributions: Conceptualization, C.B. and L.-G.Z.; methodology, M.P.; data curation, L.-G.Z. and M.P.; writing—original draft preparation, L.-G.Z. C.B. and M.P.; writing-review and editing, C.B. and M.P.; supervision, C.B.; project administration, C.B.; All authors have read and agreed to the published version of the manuscript.

Funding: This research was funded by Research Institute of the University of Bucharest (ICUB), grant number $9737 / 2019$ and by the research contract UB 10234/2020 of the University of Bucharest.

Acknowledgments: L.-G. Zamfir was supported by the Romanian Young Academy, which is funded by Stiftung Mercator and the Alexander von Humboldt Foundation for the period 2020-2022.

Conflicts of Interest: The authors declare no conflict of interest.

\section{Abbreviations}

1-AP-CNHs, 1-aminopyrene modified carbon nanohorns; 3D GF, 3D graphene; 11-MUA, 11-mercaptoundecanoic acid; 16-PHA, 16 -phosphonohexadecanoic acid; $\beta$-CD, $\beta$-cyclodextrin; $\beta$-MnO2 CNs, manganese oxide cacti-like nanostructures; $\mathrm{AAP}$, acetamiprid; $\mathrm{Ab}$, antibody; $\mathrm{ACA}$, anti-cortisol antibody; ACEK, alternating current electro-kinetics; ACET, alternating current electrothermal; AOO, anodized aluminum oxide; APTES, 3-Aminopropyltriethoxysilane; Apt, aptamer; AuIDE, Au interdigitated electrode; AuNCs, Au nanocones; AuNP, gold nanoparticle; ATZ, atrazine; BDD, boron-doped diamond; BDE-47, 2,2',4,4'-Tetrabromodiphenyl ether; C60, fullerene C60; CBZ, carbendazim; Cdl, double-layer capacitance; CDs, carbon dots; C-ELISA, competitive enzyme-linked immunosorbent assay; CNHs, carbon nanohorns; DAD, 1,10-diaminodecane; DBP, dibutyl phthalate; DBDE, decabromodiphenyl ether; DDT, Dichlorodiphenyltrichloroethane; DEHP, di(2-ethylhexyl) phthalate; E2, 17 $\beta$-estradiol; EDC, $\mathrm{N}$-(3-dimethylaminopropyl)-N-ethylcarbodiimide hydrochloride; EIS, electrochemical impedance spectroscopy; E-MIP, electropolymerized molecularly imprinted polymer; ER- $\alpha$, estrogen receptor-alpha; ET, electron transfer; Fe(III)TMPP, triflato 5,10,15,20-tetrakis(4-metoxyphenyl)porphyrinato) iron(III); GCE, glassy carbon electrode; GFE, graphite felt electrode; GO, graphene oxide; GOPTS, (3-glycidyloxypropyl) triethoxysilan; GQD, graphene quantum dots; IDE, interdigitated electrode; ITO, indium tin oxide electrode; $\mathrm{MB}$, methylene blue; $\mathrm{MCH}$, 6-mercapto-1-hexanol; MC-LR, microcystin-LR; MEA, monoethanolamine; MPA, Mercaptopropionic acid; MIPs, molecularly-imprinted polymers; MNF, electrospun manganese oxide nanofibers; MNPs, magnetic nanoparticles; MOF, metal-organic framework; MWCNTs, multi-walled carbon nanotubes; nano-CP, nano-particle comprised conducting polymer; NHS, N-hydroxysuccinimide; NorFLX, norfluoxetine; o-PD, o-phenylenediamine; PBDEs, polybrominated diphenyl ethers; PCBs, polychlorinated biphenyls; PCB-77, 3,3' '4, '4' -tetrachlorobiphenyl; PdNPs, palladium nanoparticles; PDA, polydopamine; PFOS, perfluorooctane sulfonate; PGE, pencil graphite electrode; poly(Gly), polyglycine; PMMA, poly(methylmetacrylate); PPY, polypyrrole; PPY-NTA, pyrrole-nitrilotriacetic acid monomer; Pt NPs, platinum nanoparticles; PyCD, pyrenecyclodextrin; $R_{c} t$, charge-transfer resistance; $R m t$, mass transfer resistance; rGO, reduced graphene oxide; rGONR, reduced graphene oxide nanoribbon; SAMs, self-assembled monolayer; SAW, surface acoustic wave; s-BLM, bilayer lipid membranes; SPA, 3-sulfanylpropionoic acid; SPCE, screen-printed carbon electrode; SPE, screen-printed electrode; SPGE, screen-printed gold electrode; SPR, surface plasmon resonance; SWCNT, single-walled carbon nanotube; W, Warburg impedance; ZEN, zearalenone; ZnONR, Zinc Oxide nanorods.

\section{References}

1. Soto, A.M.; Sonnenschein, C. Environmental causes of cancer: Endocrine disruptors as carcinogens. Nat. Rev. Endocrinol. 2010, 6, 363-370. [CrossRef] [PubMed]

2. Bedia, C.; Dalmau, N.; Jaumot, J.; Tauler, R. Phenotypic malignant changes and untargeted lipidomic analysis of long-term exposed prostate cancer cells to endocrine disruptors. Environ. Res. 2015, 140, 18-31. [CrossRef] [PubMed]

3. Troisi, R.; Hatch, E.E.; Palmer, J.R.; Titus, L.; Sampson, J.N.; Xu, X.; Hoover, R.N. Estrogen Metabolism in Postmenopausal Women Exposed In Utero to Diethylstilbestrol. Cancer Epidemiol. Biomark. Prev. 2018, 27, 1208-1213. [CrossRef] [PubMed]

4. Giulivo, M.; Lopez de Alda, M.; Capri, E.; Barcelo, D. Human exposure to endocrine disrupting compounds: Their role in reproductive systems, metabolic syndrome and breast cancer. A review. Environ. Res. 2016, 151, 251-264. [CrossRef] [PubMed] 
5. Ohore, O.E.; Zhang, S. Endocrine disrupting effects of bisphenol A exposure and recent advances on its removal by water treatment systems. A review. Sci. Afr. 2019, 5, e00135. [CrossRef]

6. White, S.S.; Fenton, S.E.; Hines, E.P. Endocrine disrupting properties of perfluorooctanoic acid. J. Steroid Biochem. Mol. Biol. 2011, 127, 16-26. [CrossRef]

7. Metzler, M.; Pfeiffer, E. Chemistry of Natural and Anthropogenic Endocrine Active Compounds. In Endocrine Disruptors-Part I; Metzler, M., Ed.; Springer: Berlin/Heidelberg, Germany, 2001; pp. 63-80.

8. Benigni, P.; Thompson, C.J.; Ridgeway, M.E.; Park, M.A.; Fernandez-Lima, F. Targeted High-Resolution Ion Mobility Separation Coupled to Ultrahigh-Resolution Mass Spectrometry of Endocrine Disruptors in Complex Mixtures. Anal. Chem. 2015, 87, 4321-4325. [CrossRef]

9. Pintado-Herrera, M.G.; González-Mazo, E.; Lara-Martín, P.A. In-cell clean-up pressurized liquid extraction and gas chromatography-tandem mass spectrometry determination of hydrophobic persistent and emerging organic pollutants in coastal sediments. J. Chromatogr. A 2016, 1429, 107-118. [CrossRef]

10. Pérez, R.L.; Escandar, G.M. Multivariate calibration-assisted high-performance liquid chromatography with dual UV and fluorimetric detection for the analysis of natural and synthetic sex hormones in environmental waters and sediments. Environ. Pollut. 2016, 209, 114-122. [CrossRef]

11. Barreca, S.; Busetto, M.; Colzani, L.; Clerici, L.; Daverio, D.; Dellavedova, P.; Balzamo, S.; Calabretta, E.; Ubaldi, V. Determination of estrogenic endocrine disruptors in water at sub-ng L-1 levels in compliance with Decision 2015/495/EU using offline-online solid phase extraction concentration coupled with high performance liquid chromatography-tandem mass spectrometry. Microchem. J. 2019, 147, 1186-1191. [CrossRef]

12. Myridakis, A.; Balaska, E.; Gkaitatzi, C.; Kouvarakis, A.; Stephanou, E.G. Determination and separation of bisphenol A, phthalate metabolites and structural isomers of parabens in human urine with conventional high-pressure liquid chromatography combined with electrospray ionisation tandem mass spectrometry. Anal. Bioanal. Chem. 2015, 407, 2509-2518. [CrossRef] [PubMed]

13. Stanczyk, F.Z.; Archer, D.F.; Bhavnani, B.R. Ethinyl estradiol and $17 \beta$-estradiol in combined oral contraceptives: Pharmacokinetics, pharmacodynamics and risk assessment. Contraception 2013, 87, 706-727. [CrossRef] [PubMed]

14. Kong, D.; Zhang, J.; Hou, X.; Zhang, S.; Tan, J.; Chen, Y.; Yang, W.; Zeng, J.; Han, Y.; Liu, X.; et al. Acetamiprid inhibits testosterone synthesis by affecting the mitochondrial function and cytoplasmic adenosine triphosphate production in rat Leydig cellst. Biol. Reprod. 2016, 96, 254-265. [CrossRef] [PubMed]

15. Silveyra, G.R.; Canosa, I.S.; Zanitti, M.; Rodríguez, E.M.; Medesani, D.A. Interference of an atrazine commercial formulation with the endocrine control of ovarian growth exerted by the eyestalks. Environ. Sci. Pollut. Res. 2020, 27, 965-973. [CrossRef]

16. Sheikh, I.A. Endocrine-disrupting potential of polybrominated diphenyl ethers (PBDEs) on androgen receptor signaling: A structural insight. Struct. Chem. 2020. [CrossRef]

17. Loffredo, L.F.; Coden, M.E.; Berdnikovs, S. Endocrine Disruptor Bisphenol A (BPA) Triggers Systemic Para-Inflammation and is Sufficient to Induce Airway Allergic Sensitization in Mice. Nutrients 2020, 12, 343. [CrossRef]

18. Yan, S.; Wang, M.; Zha, J.; Zhu, L.; Li, W.; Luo, Q.; Sun, J.; Wang, Z. Environmentally Relevant Concentrations of Carbamazepine Caused Endocrine-Disrupting Effects on Nontarget Organisms, Chinese Rare Minnows (Gobiocypris rarus). Environ. Sci. Technol. 2018, 52, 886-894. [CrossRef]

19. Oray, M.; Abu Samra, K.; Ebrahimiadib, N.; Meese, H.; Foster, C.S. Long-term side effects of glucocorticoids. Expert Opin. Drug. Saf. 2016, 15, 457-465. [CrossRef]

20. Xie, F.; Chen, X.; Weng, S.; Xia, T.; Sun, X.; Luo, T.; Li, P. Effects of two environmental endocrine disruptors di-n-butyl phthalate (DBP) and mono-n-butyl phthalate (MBP) on human sperm functions in vitro. Reprod. Toxicol. 2019, 83, 1-7. [CrossRef]

21. Soto, A.M.; Sonnenschein, C. Endocrine disruptors: DDT, endocrine disruption and breast cancer. Nat. Rev. Endocrinol. 2015, 11, 507-508. [CrossRef]

22. Rowdhwal, S.S.S.; Chen, J. Toxic Effects of Di-2-ethylhexyl Phthalate: An Overview. BioMed Res. Int. 2018, 2018, 1750368. [CrossRef] [PubMed]

23. Mallia, V.; Ivanova, L.; Eriksen, G.S.; Harper, E.; Connolly, L.; Uhlig, S. Investigation of In Vitro Endocrine Activities of Microcystis and Planktothrix Cyanobacterial Strains. Toxins 2020, 12, 228. [CrossRef] [PubMed] 
24. Hudon Thibeault, A.-A.; Laurent, L.; Vo Duy, S.; Sauvé, S.; Caron, P.; Guillemette, C.; Sanderson, J.T.; Vaillancourt, C. Fluoxetine and its active metabolite norfluoxetine disrupt estrogen synthesis in a co-culture model of the feto-placental unit. Mol. Cell. Endocrinol. 2017, 442, 32-39. [CrossRef] [PubMed]

25. Bell, M.R. Endocrine-disrupting actions of PCBs on brain development and social and reproductive behaviors. Curr. Opin. Pharmacol. 2014, 19, 134-144. [CrossRef]

26. Lo, E.M.; Rodriguez, K.M.; Pastuszak, A.W.; Khera, M. Alternatives to Testosterone Therapy: A Review. Sex. Med. Rev. 2018, 6, 106-113. [CrossRef]

27. Mitra, S.; Srivastava, A.; Khandelwal, S. Long term impact of the endocrine disruptor tributyltin on male fertility following a single acute exposure. Environ. Toxicol. 2017, 32, 2295-2304. [CrossRef]

28. Kowalska, K.; Habrowska-Górczyńska, D.E.; Piastowska-Ciesielska, A.W. Zearalenone as an endocrine disruptor in humans. Environ. Toxicol. Pharmacol. 2016, 48, 141-149. [CrossRef]

29. Lasia, A. Definition of Impedance and Impedance of Electrical Circuits. In Electrochemical Impedance Spectroscopy and Its Applications; Lasia, A., Ed.; Springer: New York, NY, USA, 2014; pp. 7-66.

30. Bahadır, E.B.; Sezgintürk, M.K. A review on impedimetric biosensors. Artif. Cells Nanomed. Biotechnol. 2016, 44, 248-262. [CrossRef]

31. Schrattenecker, J.D.; Heer, R.; Melnik, E.; Maier, T.; Fafilek, G.; Hainberger, R. Hexaammineruthenium (II)/(III) as alternative redox-probe to Hexacyanoferrat (II)/(III) for stable impedimetric biosensing with gold electrodes. Biosens. Bioelectron. 2019, 127, 25-30. [CrossRef]

32. Ertürk, G.; Mattiasson, B. Capacitive Biosensors and Molecularly Imprinted Electrodes. Sensors 2017, 17, 390. [CrossRef]

33. Thévenot, D.R.; Toth, K.; Durst, R.A.; Wilson, G.S. Electrochemical biosensors: Recommended definitions and classification. Biosens. Bioelectron. 2001, 16, 121-131. [PubMed]

34. Jaffrezic-Renault, N.; Kou, J.; Tan, D.; Guo, Z. New trends in the electrochemical detection of endocrine disruptors in complex media. Anal. Bioanal. Chem. 2020, 412, 5913-5923. [CrossRef] [PubMed]

35. Luka, G.; Ahmadi, A.; Najjaran, H.; Alocilja, E.; DeRosa, M.; Wolthers, K.; Malki, A.; Aziz, H.; Althani, A.; Hoorfar, M. Microfluidics Integrated Biosensors: A Leading Technology towards Lab-on-a-Chip and Sensing Applications. Sensors 2015, 15, 30011-30031. [CrossRef] [PubMed]

36. Khanna, M.; Roy, S.; Kumar, R.; Wadhwa, S.; Mathur, A.; Dubey, A.K. MnO2 Based Bisphenol-A Electrochemical Sensor Using Micro-Fluidic Platform. IEEE Sens. J. 2018, 18, 2206-2210. [CrossRef]

37. Cheng, Y.H.; Barpaga, D.; Soltis, J.A.; Shutthanandan, V.; Kargupta, R.; Han, K.S.; McGrail, B.P.; Motkuri, R.K.; Basuray, S.; Chatterjee, S. Metal-Organic Framework-Based Microfluidic Impedance Sensor Platform for Ultrasensitive Detection of Perfluorooctanesulfonate. ACS Appl. Mater. Interfaces 2020, 12, 10503-10514. [CrossRef]

38. Le Noir, M.; Lepeuple, A.-S.; Guieysse, B.; Mattiasson, B. Selective removal of $17 \beta$-estradiol at trace concentration using a molecularly imprinted polymer. Water Res. 2007, 41, 2825-2831. [CrossRef]

39. Crapnell, R.D.; Hudson, A.; Foster, C.W.; Eersels, K.; Grinsven, B.V.; Cleij, T.J.; Banks, C.E.; Peeters, M. Recent Advances in Electrosynthesized Molecularly Imprinted Polymer Sensing Platforms for Bioanalyte Detection. Sensors 2019, 19, 1204. [CrossRef]

40. Saylan, Y.; Akgönüllü, S.; Yavuz, H.; Ünal, S.; Denizli, A. Molecularly Imprinted Polymer Based Sensors for Medical Applications. Sensors 2019, 19, 1279. [CrossRef]

41. Wu, X.; Wang, X.; Lu, W.; Wang, X.; Li, J.; You, H.; Xiong, H.; Chen, L. Water-compatible temperature and magnetic dual-responsive molecularly imprinted polymers for recognition and extraction of bisphenol A. J. Chromatogr. A 2016, 1435, 30-38. [CrossRef]

42. Miao, J.; Liu, A.; Wu, L.; Yu, M.; Wei, W.; Liu, S. Magnetic ferroferric oxide and polydopamine molecularly imprinted polymer nanocomposites based electrochemical impedance sensor for the selective separation and sensitive determination of dichlorodiphenyltrichloroethane (DDT). Anal. Chim. Acta 2020, 1095, 82-92. [CrossRef]

43. Radi, A.; Eissa, A.; Wahdan, T. Molecularly Imprinted Impedimetric Sensor for Determination of Mycotoxin Zearalenone. Electroanalysis 2020, 32, 1788-1794. [CrossRef]

44. Liu, W.; Li, H.; Yu, S.; Zhang, J.; Zheng, W.; Niu, L.; Li, G. Poly(3,6-diamino-9-ethylcarbazole) based molecularly imprinted polymer sensor for ultra-sensitive and selective detection of $17-\beta$-estradiol in biological fluids. Biosens. Bioelectron. 2018, 104, 79-86. [CrossRef] [PubMed] 
45. Che Lah, N.F.; Ahmad, A.L.; Low, S.C.; Shoparwe, N.F. The role of porogen-polymer complexation in atrazine imprinted polymer to work as an electrochemical sensor in water. J. Environ. Chem. Eng. 2019, 7, 103500. [CrossRef]

46. Apodaca, D.C.; Pernites, R.B.; Ponnapati, R.; Del Mundo, F.R.; Advincula, R.C. Electropolymerized Molecularly Imprinted Polymer Film: EIS Sensing of Bisphenol A. Macromolecules 2011, 44, 6669-6682. [CrossRef]

47. Bolat, G.; Yaman, Y.T.; Abaci, S. Molecularly imprinted electrochemical impedance sensor for sensitive dibutyl phthalate (DBP) determination. Sens. Actuators B Chem. 2019, 299, 127000. [CrossRef]

48. Zia, A.I.; Mukhopadhyay, S.C.; Yu, P.-L.; Al-Bahadly, I.H.; Gooneratne, C.P.; Kosel, J. Rapid and molecular selective electrochemical sensing of phthalates in aqueous solution. Biosens. Bioelectron. 2015, 67, 342-349. [CrossRef]

49. Zia, A.I.; Mukhopadhyay, S.C.; Al-Bahadly, I.H.; Yu, P.L.; Gooneratne, C.P.; Kosel, J. Introducing molecular selectivity in rapid impedimetric sensing of phthalates. In Proceedings of the 2014 IEEE International Instrumentation and Measurement Technology Conference (I2MTC), Montevideo, Uruguay, 12-15 May 2014; pp. 838-843.

50. Liu, W.; Ma, Y.; Sun, G.; Wang, S.; Deng, J.; Wei, H. Molecularly imprinted polymers on graphene oxide surface for EIS sensing of testosterone. Biosens. Bioelectron. 2017, 92, 305-312. [CrossRef]

51. Zamora-Gálvez, A.; Mayorga-Matinez, C.C.; Parolo, C.; Pons, J.; Merkoçi, A. Magnetic nanoparticle-molecular imprinted polymer: A new impedimetric sensor for tributyltin detection. Electrochem. Commun. 2017, 82, 6-11. [CrossRef]

52. Ensafi, A.A.; Amini, M.; Rezaei, B. Molecularly imprinted electrochemical aptasensor for the attomolar detection of bisphenol A. Microchim. Acta 2018, 185, 265. [CrossRef]

53. Kumar, P.; Deep, A.; Kim, K.-H. Metal organic frameworks for sensing applications. Trends Anal. Chem. 2015, 73, 39-53. [CrossRef]

54. Sireesha, M.; Jagadeesh Babu, V.; Kranthi Kiran, A.S.; Ramakrishna, S. A review on carbon nanotubes in biosensor devices and their applications in medicine. Nanocomposites 2018, 4, 36-57. [CrossRef]

55. Wei, Y.; Kong, L.-T.; Yang, R.; Wang, L.; Liu, J.-H.; Huang, X.-J. Electrochemical impedance determination of polychlorinated biphenyl using a pyrenecyclodextrin-decorated single-walled carbon nanotube hybrid. Chem. Comm. 2011, 47, 5340-5342. [CrossRef] [PubMed]

56. Hsine, Z.; Bizid, S.; Zahou, I.; Ben Haj Hassen, L.; Nasri, H.; Mlika, R. A highly sensitive impedimetric sensor based on iron (III) porphyrin and thermally reduced graphene oxide for detection of Bisphenol A. Synth. Met. 2018, 244, 27-35. [CrossRef]

57. Xiong, S.; Cheng, J.; He, L.; Wang, M.; Zhang, X.; Wu, Z. Detection of di(2-ethylhexyl)phthalate through graphene- $\beta$-cyclodextrin composites by electrochemical impedance spectroscopy. Anal. Methods 2014, 6, 1736-1742. [CrossRef]

58. Xiong, S.; Cheng, J.; He, L.; Cai, D.; Zhang, X.; Wu, Z. Fabrication of $\beta$-cyclodextrin/graphene/1,10diaminodecane composite on glassy carbon electrode and impedimetric method for $\mathrm{Di}(2$-ethyl hexyl) phthalate determination. J. Electroanal. Chem. 2015, 743, 18-24. [CrossRef]

59. Duffy, G.F.; Moore, E.J. Electrochemical Immunosensors for Food Analysis: A Review of Recent Developments. Anal. Lett. 2017, 50, 1-32. [CrossRef]

60. Li, X.; Huang, Y.; Chen, M.; Tong, Y.; Zhang, C. A label-free electrochemical bisphenol A immunosensor based on chlorogenic acid as a redox probe. Anal. Methods 2017, 9, 2183-2188. [CrossRef]

61. Singh, A.C.; Bacher, G.; Bhand, S. A label free immunosensor for ultrasensitive detection of $17 \beta$-Estradiol in water. Electrochim. Acta 2017, 232, 30-37. [CrossRef]

62. Supraja, P.; Singh, V.; Vanjari, S.R.K.; Govind Singh, S. Electrospun CNT embedded ZnO nanofiber based biosensor for electrochemical detection of Atrazine: A step closure to single molecule detection. Microsyst. Nanoeng. 2020, 6, 3. [CrossRef]

63. Chen, Y.; Zhang, S.; Hong, Z.; Lin, Y.; Dai, H. A mimotope peptide-based dual-signal readout competitive enzyme-linked immunoassay for non-toxic detection of zearalenone. J. Mater. Chem. B 2019, 7, 6972-6980. [CrossRef]

64. Kang, B.; Kim, J.H.; Kim, S.; Yoo, K.-H. Aptamer-modified anodized aluminum oxide-based capacitive sensor for the detection of bisphenol A. Appl. Phys. Lett. 2011, 98, 073703. [CrossRef] 
65. Cui, H.; Wu, J.; Eda, S.; Chen, J.; Chen, W.; Zheng, L. Rapid capacitive detection of femtomolar levels of bisphenol A using an aptamer-modified disposable microelectrode array. Microchim. Acta 2015, 182, 2361-2367. [CrossRef]

66. Mirzajani, H.; Cheng, C.; Wu, J.; Chen, J.; Eda, S.; Najafi Aghdam, E.; Badri Ghavifekr, H. A highly sensitive and specific capacitive aptasensor for rapid and label-free trace analysis of Bisphenol A (BPA) in canned foods. Biosens. Bioelectron. 2017, 89, 1059-1067. [CrossRef] [PubMed]

67. Singh, A.C.; Asif, M.H.; Bacher, G.; Danielsson, B.; Willander, M.; Bhand, S. Nanoimmunosensor based on $\mathrm{ZnO}$ nanorods for ultrasensitive detection of 17ß-Estradiol. Biosens. Bioelectron. 2019, 126, 15-22. [CrossRef] [PubMed]

68. Supraja, P.; Tripathy, S.; Krishna Vanjari, S.R.; Singh, V.; Singh, S.G. Label free, electrochemical detection of atrazine using electrospun $\mathrm{Mn} 2 \mathrm{O} 3$ nanofibers: Towards ultrasensitive small molecule detection. Sens. Actuators B Chem. 2019, 285, 317-325. [CrossRef]

69. Radhakrishnan, R.; Suni, I.I.; Bever, C.S.; Hammock, B.D. Impedance Biosensors: Applications to Sustainability and Remaining Technical Challenges. ACS Sustain. Chem. Eng. 2014, 2, 1649-1655. [CrossRef]

70. Rahman, M.A.; Shiddiky, M.J.A.; Park, J.-S.; Shim, Y.-B. An impedimetric immunosensor for the label-free detection of bisphenol A. Biosens. Bioelectron. 2007, 22, 2464-2470. [CrossRef]

71. Zhou, Q.; Kannan, P.; Natarajan, B.; Maiyalagan, T.; Subramanian, P.; Jiang, Z.; Mao, S. MnO2 cacti-like nanostructured platform powers the enhanced electrochemical immunobiosensing of cortisol. Sens. Actuators B Chem. 2020, 317, 128134. [CrossRef]

72. Liang, Y.-R.; Zhang, Z.-M.; Liu, Z.-J.; Wang, K.; Wu, X.-Y.; Zeng, K.; Meng, H.; Zhang, Z. A highly sensitive signal-amplified gold nanoparticle-based electrochemical immunosensor for dibutyl phthalate detection. Biosens. Bioelectron. 2017, 91, 199-202. [CrossRef]

73. Zhang, W.; Han, C.; Jia, B.; Saint, C.; Nadagouda, M.; Falaras, P.; Sygellou, L.; Vogiazi, V.; Dionysiou, D.D. A 3D graphene-based biosensor as an early microcystin-LR screening tool in sources of drinking water supply. Electrochim. Acta 2017, 236, 319-327. [CrossRef]

74. Wang, J.; Zhang, S.; Dai, H.; Lin, Y. Strip-shaped Co3O4 as a peroxidase mimic in a signal-amplified impedimetric zearalenone immunoassay. Microchim. Acta 2019, 187, 75. [CrossRef] [PubMed]

75. Ke, H.; Liu, M.; Zhuang, L.; Li, Z.; Fan, L.; Zhao, G. A Fetomolar Level 17ß-estradiol Electrochemical Aptasensor Constructed On Hierachical Dendritic Gold Modified Boron-Doped Diamond Electrode. Electrochim. Acta 2014, 137, 146-153. [CrossRef]

76. Mat Zaid, M.H.; Abdullah, J.; Rozi, N.; Mohamad Rozlan, A.A.; Abu Hanifah, S. A Sensitive Impedimetric Aptasensor Based on Carbon Nanodots Modified Electrode for Detection of 17ß-Estradiol. Nanomaterials 2020, 10, 1346. [CrossRef] [PubMed]

77. Fan, L.; Zhao, G.; Shi, H.; Liu, M.; Li, Z. A highly selective electrochemical impedance spectroscopy-based aptasensor for sensitive detection of acetamiprid. Biosens. Bioelectron. 2013, 43, 12-18. [CrossRef] [PubMed]

78. Fei, A.; Liu, Q.; Huan, J.; Qian, J.; Dong, X.; Qiu, B.; Mao, H.; Wang, K. Label-free impedimetric aptasensor for detection of femtomole level acetamiprid using gold nanoparticles decorated multiwalled carbon nanotube-reduced graphene oxide nanoribbon composites. Biosens. Bioelectron. 2015, 70, 122-129. [CrossRef]

79. Madianos, L.; Tsekenis, G.; Skotadis, E.; Patsiouras, L.; Tsoukalas, D. A highly sensitive impedimetric aptasensor for the selective detection of acetamiprid and atrazine based on microwires formed by platinum nanoparticles. Biosens. Bioelectron. 2018, 101, 268-274. [CrossRef]

80. Kazane, I.; Gorgy, K.; Gondran, C.; Spinelli, N.; Zazoua, A.; Defrancq, E.; Cosnier, S. Highly Sensitive Bisphenol-A Electrochemical Aptasensor Based on Poly(Pyrrole-Nitrilotriacetic Acid)-Aptamer Film. Anal. Chem. 2016, 88, 7268-7273. [CrossRef]

81. Ma, Y.; Liu, J.; Li, H. Diamond-based electrochemical aptasensor realizing a femtomolar detection limit of bisphenol A. Biosens. Bioelectron. 2017, 92, 21-25. [CrossRef]

82. Jalalvand, A.R.; Haseli, A.; Farzadfar, F.; Goicoechea, H.C. Fabrication of a novel biosensor for biosensing of bisphenol A and detection of its damage to DNA. Talanta 2019, 201, 350-357. [CrossRef]

83. Eissa, S.; Zourob, M. Selection and Characterization of DNA Aptamers for Electrochemical Biosensing of Carbendazim. Anal. Chem. 2017, 89, 3138-3145. [CrossRef] 
84. Zhu, C.; Liu, D.; Chen, Z.; Li, L.; You, T. An ultra-sensitive aptasensor based on carbon nanohorns/gold nanoparticles composites for impedimetric detection of carbendazim at picogram levels. J. Colloid Interface Sci. 2019, 546, 92-100. [CrossRef] [PubMed]

85. Lu, Q.; Liu, X.; Hou, J.; Yuan, Q.; Li, Y.; Chen, S. Selection of Aptamers Specific for DEHP Based on ssDNA Library Immobilized SELEX and Development of Electrochemical Impedance Spectroscopy Aptasensor. Molecules 2020, 25, 747. [CrossRef] [PubMed]

86. La Spina, R.; Ferrero, V.E.V.; Aiello, V.; Pedotti, M.; Varani, L.; Lettieri, T.; Calzolai, L.; Haasnoot, W.; Colpo, P. Label-Free Biosensor Detection of Endocrine Disrupting Compounds Using Engineered Estrogen Receptors. Biosensors 2017, 8, 1. [CrossRef] [PubMed]

87. Xia, W.; Li, Y.; Wan, Y.; Chen, T.; Wei, J.; Lin, Y.; Xu, S. Electrochemical biosensor for estrogenic substance using lipid bilayers modified by Au nanoparticles. Biosens. Bioelectron. 2010, 25, 2253-2258. [CrossRef] [PubMed]

88. Im, J.-E.; Han, J.-A.; Kim, B.K.; Han, J.H.; Park, T.S.; Hwang, S.; In Cho, S.; Lee, W.-Y.; Kim, Y.-R. Electrochemical detection of estrogen hormone by immobilized estrogen receptor on Au electrode. Surf. Coat. Technol. 2010, 205, S275-S278. [CrossRef]

89. Kim, B.K.; Li, J.; Im, J.-E.; Ahn, K.-S.; Park, T.S.; Cho, S.I.; Kim, Y.-R.; Lee, W.-Y. Impedometric estrogen biosensor based on estrogen receptor alpha-immobilized gold electrode. J. Electroanal. Chem. 2012, 671, 106-111. [CrossRef]

90. Li, J.; Kim, B.K.; Wang, K.-K.; Im, J.-E.; Choi, H.N.; Kim, D.-H.; Cho, S.I.; Lee, W.-Y.; Kim, Y.-R. Sensing Estrogen with Electrochemical Impedance Spectroscopy. J. Anal. Methods Chem. 2016, 2016, 9081375. [CrossRef]

91. Ba, S.; Vinoth Kumar, V. Recent developments in the use of tyrosinase and laccase in environmental applications. Crit. Rev. Biotechnol. 2017, 37, 819-832. [CrossRef]

92. Asadgol, Z.; Forootanfar, H.; Rezaei, S.; Mahvi, A.H.; Faramarzi, M.A. Removal of phenol and bisphenol-A catalyzed by laccase in aqueous solution. J. Environ. Health Sci. Eng. 2014, 12, 93. [CrossRef]

93. Singh, N.; Reza, K.K.; Ali, M.A.; Agrawal, V.V.; Biradar, A.M. Self assembled DC sputtered nanostructured rutile $\mathrm{TiO} 2$ platform for bisphenol A detection. Biosens. Bioelectron. 2015, 68, 633-641. [CrossRef]

94. Fernandes, P.M.V.; Campiña, J.M.; Silva, A.F. A layered nanocomposite of laccase, chitosan, and Fe3O4 nanoparticles-reduced graphene oxide for the nanomolar electrochemical detection of bisphenol A. Microchim. Acta 2020, 187, 262. [CrossRef] [PubMed]

95. Liu, Q.; Wang, J.; Boyd, B.J. Peptide-based biosensors. Talanta 2015, 136, 114-127. [CrossRef] [PubMed]

96. Pavan, S.; Berti, F. Short peptides as biosensor transducers. Anal. Bioanal. Chem. 2012, 402, 3055-3070. [CrossRef] [PubMed]

97. Gutés, A.; Lee, B.-Y.; Carraro, C.; Mickelson, W.; Lee, S.-W.; Mabouduan, R. Impedimetric graphene-based biosensors for the detection of polybrominated diphenyl ethers. Nanoscale 2013, 5, 6048-6052. [CrossRef]

98. Melamed, S.; Elad, T.; Belkin, S. Microbial sensor cell arrays. Curr. Opin. Biotechnol. 2012, 23, 2-8. [CrossRef]

99. Gawrys, M.D.; Hartman, I.; Landweber, L.F.; Wood, D.W. Use of engineered Escherichia coli cells to detect estrogenicity in everyday consumer products. J. Chem. Technol. Biot. 2009, 84, 1834-1840. [CrossRef]

100. Furst, A.L.; Hoepker, A.C.; Francis, M.B. Quantifying Hormone Disruptors with an Engineered Bacterial Biosensor. ACS Cent. Sci. 2017, 3, 110-116. [CrossRef]

101. Garrote, B.L.; Santos, A.; Bueno, P.R. Perspectives on and Precautions for the Uses of Electric Spectroscopic Methods in Label-free Biosensing Applications. ACS Sens. 2019, 4, 2216-2227. [CrossRef]

102. Muñoz, J.; Montes, R.; Baeza, M. Trends in electrochemical impedance spectroscopy involving nanocomposite transducers: Characterization, architecture surface and bio-sensing. Trends Anal. Chem. 2017, 97, 201-215. [CrossRef]

Publisher's Note: MDPI stays neutral with regard to jurisdictional claims in published maps and institutional affiliations. 